\title{
Theory and research in strategic management: Swings of a pendulum
}

\author{
Robert E. Hoskisson \\ University of Oklahoma \\ Michael A. Hitt \\ Texas A\&M University \\ William P. Wan \\ Daphne Yiu \\ University of Oklahoma
}

\begin{abstract}
The development of the field of strategic management within the last two decades has been dramatic. While its roots have been in a more applied area, often referred to as business policy, the current field of strategic management is strongly theory based, with substantial empirical research, and is eclectic in nature. This review of the development of the field and its current position examines the field's early development and the primary theoretical and methodological bases through its history. Early developments include Chandler's (1962) Strategy and Structure and Ansoff's (1965) Corporate Strategy. These early works took on a contingency perspective (fit between strategy and structure) and a resource-based framework emphasizing internal strengths and weaknesses. Perhaps, one of the more significant contributions to the development of strategic management came from industrial organization (IO) economics, specifically the work of Michael Porter. The structure-conduct-performance framework and the notion of strategic groups, as well as providing a foundation for research on competitive dynamics, are flourishing currently. The IO paradigm also brought econometric tools to the research on strategic management. Building on the IO economics framework, the organizational economics perspective contributed transaction costs economics and agency theory to strategic management. More recent theoretical contributions focus on the resource-based view of the firm. While it has its roots in Edith Penrose's work in the late 1950s, the resource-based view was largely introduced to the field of strategic management in the 1980s and became a dominant framework in the 1990s. Based on the resource-based view or developing concurrently were research on strategic leadership, strate-
\end{abstract}

Direct all correspondence to: Robert E. Hoskisson, Michael F. Price College of Business, University of Oklahoma, Norman, OK 73019-4006; Phone: 405-325-3982; Fax: 405-325-1957; e-mail: rhoskiss@cbafac.ou. edu.

Copyright $\odot 1999$ by Elsevier Science Inc. 0149-2063 


\begin{abstract}
gic decision theory (process research) and knowledge-based view of the firm. The research methodologies are becoming increasingly sophisticated and now frequently combine both quantitative and qualitative approaches and unique and new statistical tools. Finally, this review examines the future directions, both in terms of theory and methodologies, as the study of strategic management evolves. (C) 1999 Elsevier Science Inc. All rights reserved.
\end{abstract}

The evolution of the field of strategic management since its inception has been impressive. From its "humble" beginnings as the limited content of a capstone general management course in the business school curriculum, ${ }^{1}$ strategic management is now a firmly established field in the study of business and organizations. During a relatively short period of time, this field has witnessed a significant growth in the diversity of topics and variety of research methods employed. While proliferation of topics and methods is generally encouraging, reflecting the vigor of the field, it is also worthwhile at this juncture to review the state of theory and research, examining accomplishments, and preparing for continued progress in the next century.

Owing to its roots as a more applied area, strategic management has traditionally focused on business concepts that affect firm performance. Herein, the key theories and topics of strategic management along with the methods used in its study are reviewed. The field of strategic management is eclectic in nature, but with the recent development of the resource-based view (RBV) of the firm (e.g., Barney, 1991; Wernerfelt, 1984), it has, once again, increased emphasis on firms' internal strengths and weaknesses relative to their external opportunities and threats. Calls for the use of qualitative methods to identify a firm's resources are increasing as each firm is considered to have a distinctive bundle of resources. This approach often uses single case studies as used in instruction and by early strategy scholars (e.g., Learned, Christensen, Andrews, \& Guth, 1965/1969) to study particular firm strategies or industry structure. Thus, we ask the question: Has the field of strategic management come back to its roots similar to the swing of a pendulum? To explore this question, this article traces and reviews the various major stages of developments in strategic management as an academic field of study over the last several decades. The emphasis is on the prominent theories developed and the corresponding methodologies employed in past and current strategic management research. Moreover, we explore how the field will continue to develop in the future. First, a historical overview of the development of strategic management is provided, tracing the field's disciplinary roots and depicting various swings of the pendulum.

\title{
Historical Overview
}

Theoretically, the recent rise of the RBV (e.g., Barney, 1991; Conner, 1991; Wernerfelt, 1984), together with the two closely related content areas: the knowledge-based view (e.g., Kogut \& Zander, 1992; Spender \& Grant, 1996); and strategic leadership (e.g., Cannella \& Hambrick, 1993; Finkelstein \& Hambrick, 1996; Kesner \& Sebora, 1994) have returned attention to the internal aspects of

JOURNAL OF MANAGEMENT, VOL. 25, NO. 3, 1999 
the firm. Internal firm characteristics represented the crucial research domain in the early development of the field. Early strategy researchers, such as Andrews and his colleagues (Learned et al., 1965/1969) and Ansoff (1965), were predominantly concerned with identifying firms" "best practices" that contribute to firm success. This emphasis on internal competitive resources can be traced to the early classics such as Chester Barnard's (1938) The Functions of the Executives, Philip Selznick's (1957) Leadership in Administration: A Sociological Perspective, or Edith Penrose's (1959) The Theory of the Growth of the Firm. Researchers in this stream share an interest in pondering the inner growth engines or "the black box" of the firm, and argue that a firm's continued success is chiefly a function of its internal and unique competitive resources.

In between the early development of the field in the $60 \mathrm{~s}$ and the rise of the RBV in the 1980s, however, the pendulum had swung to the other extreme and only recently has started to return. Developments in the field beginning in the 1970s fostered a move toward industrial organization (IO) economics (e.g., Porter, 1980, 1985), with its theoretical roots based on Bain $(1956,1968)$ and Mason (1939). This swing shifted the attention externally toward industry structure and competitive position in the industry. For example, the adoption of IO economics led to the development of research on strategic groups where firms are classified into categories of strategic similarity within and differences across groups (e.g., Hunt, 1972; Newman, 1973; Porter, 1973). IO economics considers structural aspects of an industry, whereas work on strategic groups is largely focused on firm groupings within an industry. Strategic groups research continues to be a focus, especially by the population ecologists building on the aforementioned work.

Reemergence of internal firm characteristics was evident in the emphasis on competitive dynamics and boundary relationships between the firm and its environment (e.g., Chen, 1996; Gimeno \& Woo, 1996; Karnani \& Wernerfelt, 1985). Although this sub-field has borrowed more substantially from the theories of IO economics, mainly oligopolistic competition (e.g., Edwards, 1955) and game theory, strategic management research on competitive dynamics uses actual firms and environments for the theory and data (D'Aveni, 1994), rather than abstract simulations. Compared to standard IO economics, it moves much closer to the firm and direct competitive rivalry between specific firms in the competitive environment (Chen, 1996).

Also, with a focus on boundary relationships, the field began to emphasize transaction costs analysis (Williamson, 1975, 1985), which examines the firmenvironment interface through a contractual or exchange-based approach. In a similar vein, agency theory, also contractual or exchanged-based, suggests that the firm can be viewed as a "nexus of contracts" (Jensen \& Meckling, 1976). Both transaction costs economics (TCE) and agency theory have their roots in Ronald Coase's (1937) influential essay "The Nature of the Firm," and especially agency theory evolved from the insights found in The Modern Corporation and Private Property (1932) by Adolf Berle and Gardiner Means. TCE has fostered much research on firm boundaries, markets versus hierarchies. For example, this work has led to many studies on the adoption of the multidivisional structure (for a 
review, see Hoskisson, Hill, \& Kim, 1993), and vertical integration and strategic alliances (Kogut, 1988). Additionally, a substantial amount of studies on corporate governance has been spawned by agency theory (Eisenhardt, 1989a; Hoskisson \& Turk, 1990). Both of these perspectives have been used to examine a variety of topics, such as mergers/acquisitions, divestitures, and downscoping (e.g., Hitt, Hoskisson, \& Ireland, 1990; Hoskisson \& Hitt, 1994), greenmail (e.g., Kosnik, 1990), and leveraged buyouts (e.g., Wiersema \& Liebeskind, 1995).

Methodologically, the pendulum appears to have swung back towards the use of more qualitative approaches, at least ideally. The case method was preferred by the early strategy scholars. There was little attempt to generalize the findings of a case to strategy making in general, except for problemsolving skills. Largely because of this approach, strategic management was not regarded as a scientific field worthy of academic study. As the field embraced IO economics, it began to emphasize scientific generalizations based on study of broader sets of firms. Additionally, strategy researchers increasingly employed multivariate statistical tools (e.g., multiple regression and cluster analysis), with large data samples primarily collected from secondary resources to test theory. The development of strategic management into a more "respected" scholarly field of study was at least partially a result of the adoption of "scientific" methods from IO economics. The development of the RBV, nevertheless, poses a major methodological problem to strategic researchers (Hitt, Gimeno, \& Hoskisson, 1998). In many respects, the study of the $\mathrm{RBV}$ requires a multiplicity of methods to identify, measure and understand firm resources, purported to reside within the boundary of a firm. More importantly, RBV proponents suggest that each firm may have distinctive resources that contribute to sustained competitive advantages. The "received" method of research using large data samples, secondary data sources, and econometric analyses appear to be inadequate, particularly when used to examine intangible firm resources, such as corporate culture (Barney, 1986b) or tacit knowledge (Kogut \& Zander, 1992). Because of the focus on a firm's idiosyncratic resources, generalizability of firm knowledge may be questionable. Although strategic management has advanced theoretically through the $\mathrm{RBV}$, the methods that complement this theoretical view are less certain and need further development. Figure 1 illustrates the various historical emphases in the field using the metaphor of swings of a pendulum. In the following sections, we review the past and the current developments of strategic management regarding theories and methodologies, and also examine how the field is likely to develop in the future.

\section{Early Development}

During the period of early development, a number of scholars made significant contributions to the later development of the field of strategic management, known, at that time, as business policy. Among the most important works are Chandler's (1962) Strategy and Structure, Ansoff's (1965) Corporate Strategy, and Learned et al.'s (1965/1969) Business Policy: Text and Cases. 

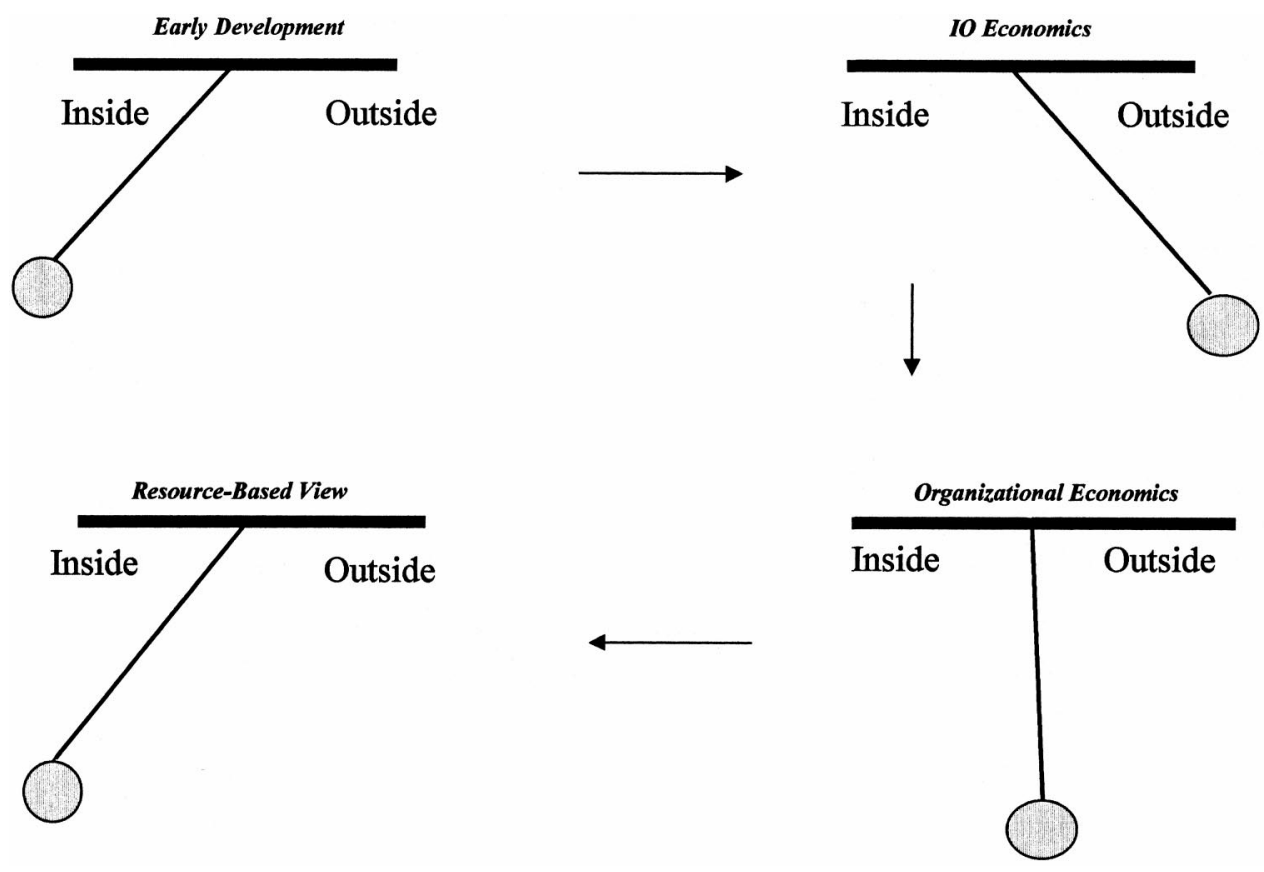

Figure 1. Swings of a Pendulum: Theoretical and Methodological Evolution in

Strategic Management

Although not explicitly mentioned on most occasions, the footprints of the earlier classics in management can be found during this early period of work on the forerunner of strategic management. For example, Barnard's (1938) detailed exposition of the cooperation and organization in business firms, as well as the managerial functions and processes therein, provided a solid foundation upon which subsequent works in strategic management were built. The crucial importance of "distinctive competence" and leadership emphasized in Selznick's (1957) study in administrative organizations coincided well with early strategy scholars' focus on firms' internal strengths and managerial capabilities. Penrose (1959) related firm growth and diversification to the "inherited" resources, especially managerial capacities, a firm possesses. Her proposition complemented Chandler's (1962) findings on the growth of the firm. ${ }^{2}$ From a behavioral perspective, Herbert Simon's (1945) Administrative Behaviors, and Cyert and March's (1963) A Behavioral Theory of the Firm also provided input into the early development of strategic management (Ansoff's, 1965, Corporate Strategy is a good example). They emphasized organizations' internal processes and characteristics, such as decision-making processes, information-processing limitations, power and coalitions, and hierarchical structures. In many respects, it is likely that the early development of strategic management thinking has been influenced, at least to a certain extent, by these early classics' detailed expositions of organizations' internal processes and focus on the important roles of managers. 


\section{Early Theories}

An important year for the field of strategic management was 1962 when Chandler's seminal work, Strategy and Structure, was published (Rumelt, Schendel, \& Teece, 1994). Chandler's work focused primarily on how large enterprises develop new administrative structures to accommodate growth, and how strategic change leads to structural change. According to Chandler, strategy is "the determination of the basic long-term goals and objectives of an enterprise, and the adoption of courses of action and the allocation of resources necessary for carrying out the goals," while structure is "the design of organization through which the enterprise is administered" (1962: 13-14). Changes in strategy are mainly responses to opportunities or needs created by changes in the external environment, such as technological innovation. As a consequence of change in strategy, complementary new structures are also devised. Moreover, the book also illuminates vividly the active role of managers in pursuing strategic changes and exploring new administrative structures.

In the preface to his book, Ansoff describes that its main focus is on strategic decisions, defined as "decisions on what kind of business the firm should seek to be in" (1965: viii). He views strategy as the "common thread" among a firm's activities and product-markets and is comprised of four components: productmarket scope, growth vector (or the changes that a firm makes in its productmarket scope), competitive advantage, and synergy.

Andrews and his colleagues considered business policy as "the study of the functions and responsibilities of general management and the problems which affect the character and success of the total enterprise" from the viewpoint "of the chief executive or general manager, whose primary responsibility is the enterprise as a whole" (Learned et al., 1965/1969: 3). More importantly, they define strategy as "the pattern of objectives, purposes, or goals and major policies and plans for achieving these goals, stated in such a way as to define what business the company is in, or is to be in and the kind of company it is or is to be" (1969: 15). They also suggest that corporate strategy is composed of two interrelated, but practically separated, aspects: formulation and implementation. The challenge in formulation is to identify and reconcile four essential components of strategy: (1) market opportunity; (2) firm competence and resources; (3) managers' personal values and aspirations; and (4) obligations to segments of society other than the stockholders. This broad definition of strategy is in accord with that of Chandler, but incorporates Selznick's (1957) "distinctive competence" and the notion of an uncertain environment (Rumelt et al., 1992). After the strategy is formulated, implementation is concerned with how resources are mobilized to accomplish the strategy and requires appropriate organization structure, systems of incentives and controls, and leadership. To Andrews and colleagues, implementation is "comprised of a series of subactivities which are primarily administrative" (1969: 19).

The three seminal works by Chandler, Ansoff, and Andrews and his colleagues, respectively, provide the foundation for the field of strategic management (e.g., Rumelt et al., 1992). Collectively, they help define a number of critical concepts and propositions in strategy, including how strategy affects performance, 
the importance of both external opportunities and internal capabilities, the notion that structure follows strategy, the practical distinction between formulation and implementation, and the active role of managers in strategic management. While there existed disagreements regarding these concepts that remained to be further specified and developed (Hofer \& Schendel, 1978), together these three works advanced the domain of strategy beyond the traditional focus of merely a capstone course about functional integration. Rumelt et al. provides an apt description: "Nearly all of the ideas and issues that concern us today can be found in at least embryonic form in these key writings of the 1960s" (1994: 18). However, Rumelt et al. (1994) overlook the contributions of Thompson (1967). He first introduced the notion of cooperative and competitive strategies and coalition formation, a forerunner of network and strategic alliance strategies. Also, his work contributed to the understanding of implementation of corporate strategy through his notion of interdependence between business units. Pooled, reciprocal, and serial interdependence are associated with the corporate strategies of unrelated diversification, related diversification and vertical integration, respectively. Although these writings form a foundation for strategic management, they were mostly processoriented to facilitate case examination, the main methodological tool of study at the time.

\section{Early Methodologies}

Works by Ansoff and Andrews, among others during the period, emphasized the normative aspect of business knowledge and are chiefly interested in identifying and developing the "best practices" that were useful for managers. The target audience of their work was managers and students aspiring to be managers. Their principal goal was to impart knowledge to practitioners, rather than to pursue knowledge for scientific advancement. In Business Policy: Text and Cases, Andrews and his colleagues described this viewpoint clearly. To them, it is impossible to "make useful generalizations about the nature of these variables or to classify their possible combinations in all situations" because there are a large number of variables unique to a certain organization or situation that guide the choice of objectives and formulation of policy (1969: 5). The study of business policy provides a familiarity with an approach to the problems, and together with the skills and attitudes, one can "combine these variables into a pattern valid for one [italics added] organization" (1969: 5). The most appropriate method for accomplishing this objective is inductive in character: in-depth case studies of single firms or industries. Generalization is practically infeasible or desirable, as each case is assumed to be too complex and unique. In addition, these authors were skeptical about the purposes of other academic disciplines, such as engineering, economics, psychology, sociology, or mathematics. These disciplines may not be appropriate for strategy studies because "Knowledge generated for one set of ends is not readily applicable to another" (Learned et al., 1965/1969: 6). Therefore, they concluded that the most valid methodology to achieve their purpose was case studies, inasmuch as the (then) strategy research had not yet advanced enough to capture significant attention. The cases used were very detailed; in the 1969 edition of Learned et al.'s Business Policy, there is a set of 
twelve cases on Olivetti plus a note on the Office Machine Industry, totaling about 180 pages.

In comparison, Chandler's Strategy and Structure is less normative or prescriptive in nature, although the research methods employed are still inductive (Rumelt et al., 1994). Chandler mainly used a historical approach to produce a detailed account of four large firms (Du Pont, General Motors, Standard Oil of New Jersey (later known as Exxon), and Sears Roebuck), considered to be representative to derive his thesis and propositions. Most of the information on the firms was gathered from publicly available sources, internal company records, and interviews. Interestingly, prior to the in-depth case studies of the four firms, an extensive survey of a larger number of firms had been conducted to provide initial knowledge of the business patterns of large U.S. enterprises. Subsequent to the case studies, Chandler extended the scope of the case study to conduct a comparative analysis among four firms to investigate what and why enterprises adopted or rejected the multidivisional structure. Therefore, unlike Andrews and Ansoff, Chandler attempted to seek generalizations regarding his thesis across a wider population of firms.

Overall, the approaches used by prominent strategy scholars during this foundation period were mainly normative or prescriptive in purpose, with in-depth case analysis as the primary research tool. To the extent that generalization is one of the goals, it is primarily achieved through induction (Rumelt, Schendel, \& Teece, 1991), perhaps facilitated by comparative studies of multiple cases similar to Chandler's approach. However, in many circumstances, generalization was not a goal nor was it deemed feasible, as maintained by Andrews and his colleagues.

Unfortunately, the heavy emphasis on the case approach and lack of generalization did not provide the base necessary for continued advancement of the field. As such, the work in this area was not well accepted by other academic fields. The need for a stronger theoretical base and for empirical tests of the theory to allow generalization produced a swing of the pendulum. Furthermore, much of the early work examined firms largely as closed systems. However, businesses, as all organizations, are open systems (Thompson, 1967). Thus, an open systems approach to understanding strategy was necessary. Because of its appropriate fit and advanced development, the swing moved toward use of economic theory to examine strategic management phenomena. Schendel and Hatten (1972) argued for a broader view of strategic management that emphasized the development of new theory from which hypotheses could be derived and empirically tested. An early example of this work was Rumelt's (1974) study. Rumelt's (1974) large sample study examined the relationship between the type of strategy and structure adopted and firm performance. His research paved the way for many subsequent studies in this area using quantitative methods.

\section{The Swing towards Industrial Organization (IO) Economics}

During the next developmental period, strategic management departed significantly theoretically and methodologically from the early period. Although Jemison (1981a) advocated that strategic management could be an amalgam of 
marketing (Biggadike, 1981), administrative behavior (Jemison, 1981b), and economics (Porter, 1981), the field moved primarily towards economics in theory and method. During this swing, the influence of economics, particularly industrial organizational (IO) economics, on strategy research was substantial, and in terms of methodology, strategy research also became much more "scientific." This swing changed strategy research from inductive, case-studies largely on a single firm or industry, to deductive, large-scale statistical analyses seeking to validate scientific hypotheses, based on models abstracted from the structure-conductperformance (S-C-P) paradigm (also known as the Bain/Mason (Bain 1956, 1968; Mason, 1939) paradigm. The most widely adopted IO framework in strategic management gave rise to the rich body of research on "strategic groups."

In the preface to the first edition of Industrial Organization, Bain stated that the book (or IO economics in general) was concerned with "the economywide complex of business enterprises ... in their function as suppliers, sellers, or buyers, of goods and services of every sort produced by enterprises" and "the environmental settings within which enterprises operate and in how they behave in these settings as producers, sellers, and buyers." He also suggested that his approach was basically "external," and "the primary unit of analysis was the industry or competing groups of firms, rather than either the individual firm or the economywide aggregate of enterprises (1968: vii). The central tenet of this paradigm, as summarized by Porter (1981), is that a firm's performance is primarily a function of the industry environment in which it competes; and because structure determines conduct (or conduct is simply a reflection of the industry environment), which in turn determines performance, conduct can be ignored and performance can, therefore, be explained by structure. Recent research, in fact, supports this argument, but also suggests that the industry environment has differential effects on large and small firms (Dean, Brown, \& Bamford, 1998). We explore these differences in a later section. Hence, the adoption of the S-C-P paradigm in strategic management naturally shifted the research focus from the firm to market structure.

Competitive dynamics (multipoint competition and competitive action-reaction), an increasingly popular research area in the current field of strategic management, also evolved partly from IO economics. This stream of research often draws heavily on works by IO economists, such as Edwards (1955) and Berheim and Whinston (1990) who introduced important concepts such as "mutual forbearance" and "spheres of influence," as well as game theoretical arguments (e.g., Camerer \& Weigelt, 1988; see Grimm \& Smith, 1997 for a review of these arguments).

In summary, this swing of the pendulum from early development of the field to IO economics had a major effect on the field in terms of both theory and method.

\section{Early Intermediate Theories}

Structure-conduct-performance framework. Porter (1980, 1985) made the most influential contribution to the field employing IO economics logic. Using a structural analysis approach, Porter (1980) outlines an analytical framework that 
can be used in understanding the structure of an industry. Structural analysis focuses on competition beyond a firm's immediate and existing rivals. Whereas the concept of industry structure remains relatively unclear in the field of IO economics, Porter's (1980) Five Forces Model, by more clearly specifying the various aspects of an industry structure, provides a useful analytic tool to assess an industry's attractiveness and facilitates competitor analysis. The ability for a firm to gain competitive advantage, according to Porter (1980, 1985, 1996), rests mainly on how well it positions and differentiates itself in an industry. The collective effects of the five forces determine the ability of firms in an industry to make profits. To Porter $(1980,1985)$, the five forces embody the rules of competition that determine industry attractiveness, and help determine a competitive strategy to "cope with and, ideally, to change those rules in the firm's favor" (1985: 4). Therefore, as a refinement of the traditional S-C-P paradigm, and also a significant contribution to the field of strategic management, Porter's framework specifies the competitive structure of an industry in a more tangible manner, as well as recognizes (albeit limitedly) the role of firms in formulating appropriate competitive strategy to achieve superior performance. Porter $(1980,1985)$ suggested generic strategies (low cost leadership, differentiation, and focus) that can be used to match particular industry foci and, thereby, build competitive advantage.

Strategic groups. Building on the IO economics perspective, strategy researchers also developed the concept of "strategic groups." In his study of the white goods industry, Hunt (1972) first introduced strategic groups as an analytic concept. To date, although there has yet to be a universal definition of strategic groups in the literature, it is commonly defined as a group of firms in the same industry following the same or similar strategies (Porter, 1980: 129). This line of research disagrees with IO economics' assumption that an industry's members differ only in market share and, hence, suggests that the presence of strategic groups in an industry poses a significant effect on the industry's performance (Newman, 1978). The concept of strategic groups is closely linked to mobility barriers (Caves \& Porter, 1977), which insulate firms in a strategic group from entry by members of another group through means such as scale economies, product differentiation, or distribution network. Mobility barriers represent crucial factors, in addition to industry-wide factors, in accounting for intra-industry differences in firm performance (Caves \& Porter, 1977; Porter, 1979). In this regard, industry is no longer viewed as a homogeneous unit to the extent that the concept of strategic groups exposes the "structure within industries" (Porter, 1979).

Although Hunt, Newman, and Porter's research on strategic groups purports to explain firm performance, the focus is actually on groups, rather than on firms. For example, Newman's (1973) study is on 34 "producer goods" industries that are all related to chemical processes, while Porter's (1973) focus is on 38 "consumer goods" industries. A series of studies conducted in the context of the brewing industry by Hatten (1974), Hatten and Schendel (1977), and Hatten, Schendel, and Cooper (1978) attempt to move the study of strategic groups to the firm level by emphasizing firm heterogeneity and conduct (strategy). As a result, 
these studies focus on strategic groups within one industry. In addition to using structural variables such as firm size and industry concentration ratio, these brewing studies employ manufacturing (e.g., capital intensity of plants), marketing (e.g., number of brands), and financial (leverage) variables, among others, as the basis for strategic group formation. Firm profitability is regarded as a function of both industry structure and strategic conduct (Cool \& Schendel, 1987; Hatten \& Schendel, 1977), thereby placing the IO economics strategic groups research squarely in strategic management.

However, despite the large number of studies on strategic groups, this stream of research faces some critical issues. Barney and Hoskisson (1990) challenged two untested assertions in strategic groups theory: (1) whether strategic groups exist; and (2) whether a firm's performance depends on strategic group membership. They argued that the existence of strategic groups in an industry rests on the researcher's presumption that strategic groups actually exist. Indeed, the resulting groupings may be merely statistical artifacts of the cluster analytic procedures used to create groups. To date, the concept of strategic groups lacks theoretical support. Furthermore, the relationship between group membership and firm performance depends critically on the existence of mobility barriers. To the extent that mobility barriers exist in an industry, there is no theory to define them in a particular industry. The attributes used for clustering strategic groups are considered mobility barriers if firm performance is different among the strategic groups. Nonetheless, Barney and Hoskisson (1990) show that different clusters of the same set of firms can produce significant differences in firm performance by group. Based on these two limitations, Barney and Hoskisson (1990) raise doubt about the contribution of strategic groups research to the field of strategic management. The concept of strategic groups, developed largely as a theoretical compromise between IO economics and strategic management, may lack theoretical validity. Recently, Wiggins and Ruefli (1995) found that stability of performance group membership is lacking, questioning the efficacy of mobility barriers and, thus, the predictive validity of strategic groups. The fundamental question is whether firms are acutely aware of their mutual dependence within their particular strategic groups (Porter, 1979), or are these groups an analytic convenience employed by researchers (Hatten \& Hatten, 1987).

Recent developments in the strategic groups research points toward several perspectives. First, the dynamic characteristics of strategic groups have been examined (e.g., Mascarenhas, 1989; Oster, 1982). This line of research found initial evidence that there is a low level of firm movement across strategic groups. Through an in-depth longitudinal study of the U.S. insurance industry, Fiegenbaum and Thomas (1995) expanded this line of research by focusing on the influence of strategic groups as a reference point for firm-level competitive strategy decisions. Another recent development in strategic group research is based on a cognitive perspective. Instead of using secondary data, Reger and Huff (1993) rely on managers' cognitive classifications to categorize strategic groups. In a related vein, Porac, Thomas, Wilson, Paton, and Kanfer (1995) also use managers' cognitive perceptions to examine how firms define a reference group of rivals. More recently, Peteraf and Shanley (1997) advance cognitive strategic 
group research by proposing a theory of strategic group identity and distinguish between groups with strong identities from those with weak identities.

Similar to the research on strategic groups, organizational ecologists recently have emphasized an evolutionary perspective in which the population of strategically similar organizations are studied longitudinally, considering both their success and failure (Barnett \& Burgelman, 1996). Such research can account for dynamics in the relationships among firms. This approach allows the examination of how strategic outcomes develop. Thus, the theory developed predicts patterns of change, rates of change and alternative paths of change (Barnett \& Burgelman, 1996). Additionally, an evolutionary perspective assumes potential variation in strategies that firms pursue over time. In particular, based on the ecological perspective, an evolutionary approach examines how selection processes affect, and are affected by, the type and rate of strategic change (Barnett \& Burgelman, 1996). Recent empirical foci of the evolutionary approach include the evolution of technological capabilities (Stuart \& Podolny, 1996) and the iterated processes of resource allocation (Noda \& Bower, 1996). Scholars adopting this evolutionary perspective argue that it is not based on a single theory. Rather, it synthesizes many theoretical perspectives, such as economic efficiency, market power, organizational learning, structural inertia, transaction costs and others (Barnett \& Burgelman, 1996). They claim it provides an integrative framework in which firm success and failure can be understood (Schendel, 1996).

Competitive dynamics. While strategic group studies represented the first swing away from industry level research, another research stream, competitive dynamics, further emphasizes the firm level in strategic management research. The essence of this stream is an explicit recognition that a firm's strategies are dynamic: Actions initiated by one firm may trigger a series of actions among the competing firms. The new competitive landscape in many industries, as described by Bettis and Hitt (1995), gives rise to relentless pace of competition, emphasizing flexibility, speed, and innovation in response to the fast-changing environment. D'Aveni (1994) coined the term "hypercompetition" to describe the condition of rapidly escalating competition characterizing many industries. The increase in competitive dynamics research signifies strategy researchers' acute awareness of the new competitive landscape in the environment. There are several areas that can be categorized as competitive dynamics research, all of which are characterized by an explicit concern for the dynamic nature of business competition. These different areas are individually known as multi-point (or multimarket) competition and competitive action-reaction.

The development of multi-point competition traces its primary theoretical origin to IO economics (mainly oligopoly theory). There are content areas in the IO economics literature concerned with competition across multiple markets (Gimeno, 1994), to include strategic groups (e.g., Greening, 1979; Newman, 1973, 1978), mutual forbearance (e.g., Edwards, 1955; Bernheim \& Whinston, 1990), and product-line rivalry (e.g., Brander \& Eaton, 1984; Bulow, Geanakoplos, \& Klemperer, 1985). While these three content areas focus on different mechanisms, the central prediction is that tacit collusion produces rivalry reduction and is more likely among firms sharing similar product-market scope because 
each of them realizes that intense rivalry will harm their individual performance. Porter (1980, 1985) and Karnani and Wernerfelt (1985) pioneered the concept of multi-point competition in the strategy literature. Illustrated with cases in the roasted coffee industry and the heavy machinery industry, Porter (1980) discussed the analysis of "cross-parry" conditions where a firm reacts to a move of a competitor by counterattacking another market of that competitor. Also relying on an inductive case study, Karnani and Wernerfelt (1985) developed two concepts, "counterattack" and "mutual foothold equilibrium," in their framework of multimarket competition that emphasizes the role of multi-market retaliation.

Large-scale econometric studies on multi-market competition have begun to appear in the strategy literature for the last several years. Using data on more than 3,000 city-pair markets in the U.S. airline industry, Gimeno and Woo (1996) examined the simultaneous role of strategic similarity and multi-market contact in competitive de-escalation. They found that strategic similarity moderately increases the intensity of rivalry, while multi-market contact strongly reduces it. Although prior literature found that strategic similarity reduces rivalry, the effect of strategic similarity on rivalry may be biased if multi-market contact is not appropriately controlled. Boeker, Goodstein, Stephan, and Murmann (1997), using a sample of hospitals located in California, found that the extent to which competitors compete in similar markets has a negative effect on market exit, providing additional evidence that market overlap results in decreases rivalry. Baum and Korn (1996) examined how market domain overlap and multi-market contact influence market entry and exit. In the context of the California commuter airline market, they found that market domain overlap increases the rates of market entry and exit, whereas increases in multi-market contact reduce them. This line of research provides new insight suggesting that close competitors are often not the most intense rivals, thus challenging the traditional assumption of firm rivalry.

Another line of research that has also drawn increasing attention is competitor action-reaction studies (see Grimm \& Smith, 1997, for a review of this work). In a series of studies using detailed data on competitive moves in the U.S. airline industry (e.g., Chen \& MacMillan, 1992; Chen \& Miller, 1994; Smith, Grimm, Chen, \& Gannon, 1989), the dynamics of how firms compete with one another and how they make use of strategies to build competitive advantages over competitors have been examined (Grimm \& Smith, 1997; Smith, Grimm, \& Gannon, 1992). Two factors characterize this line of research. First, a variety of theoretical frameworks have been employed. For instance, Smith, Grimm, Gannon, and Chen (1991) used an organizational information processing model to explain the type of action to which a firm is responding and the capabilities of the responding firm. Chen and MacMillan (1992) employed a game theoretic framework to study the effects of competitor dependence and action irreversibility on the characteristics of a firm's response to competitive moves. Adapting the expectancy-valence theory from the psychology literature, Chen and Miller (1994) investigated how competitive attacks can best minimize the chances of retaliation. Second, not only do these studies demonstrate a strong research focus on firm-level competition, but the unit of analysis is "action-reaction," which can best depict the character- 
istic of dynamic competition (Smith, Grimm, \& Gannon, 1992). Collectively, these studies generate new thinking about business competition, one that explicates the interactive, dynamic nature of firm competition.

More recently, Chen (1996) synthesized two crucial subjects in competitive dynamics: competitor analysis and interfirm rivalry. Drawing on different theories, Chen (1996) introduced two firm-specific concepts: market commonality (from multi-market competition) and resource similarity (from the resource-based view) to help elucidate the pre-battle competitive tension between two firms and to predict how firms may interact with each other as competitors. Chen's approach demonstrates the fruitfulness of integrating Porter's IO based approach ("outsidein") and the resource based approach ("inside-out") for understanding interfirm competition. Besides, unlike that of Porter's (1980) Five Forces Framework that focuses on the industry level, analysis in Chen's (1996) model focuses on the firm, emphasizing a dyadic, pair-wise analysis, yielding significant insights for competitive dynamics research.

The influence of the S-C-P paradigm has been enormous (Rumelt et al., 1994). From a firm-level analysis where identification of the "best practices" was considered the goal, much research in the field suddenly embraced the crucial importance of industry structure and its effects: strategy and performance. Although Porter's influence on the field is widely regarded as substantial (Porter, 1998a), his view about the significance of the industry is not without critics. Rumelt (1991) argued that interfirm heterogeneity within industries (business specific effects) explains firm economic performance much more than industry membership. Roquebert, Phillips, and Westfall (1996), using a different database, also support this finding. In a recent paper, Porter (1996) reaffirmed the crucial significance of strategic positioning in business competition. A recent study by McGahan and Porter (1997), with a sample including service sectors, found that (1) industry represents an important factor in affecting firm economic performance, and more specifically, (2) industry effects are more important in accounting for firm performance in service industry than in manufacturing industry. Although a lot has been learned about performance determination over the years, it appears much remains unanswered for strategy researchers.

Despite the effect of the S-C-P paradigm on the field of strategic management, the shift from the industry level to the firm level began gradually with the focus on strategic groups. The original conception of strategic groups was focused primarily on the industry level (e.g., Newman, 1978; Porter, 1979), but development of the concept by strategy researchers has been predominantly concerned with firm strategy within an industry (e.g., Purdue University's brewing industry studies). Interestingly, strategic groups research represents the first swing in the field back toward the firm level.

The ability of strategy research to internalize and develop diverse theories to study a variety of topics perhaps has enabled the field to experience exceptional development in its short history. Besides strategic groups discussed above, research on competitive dynamics clearly demonstrates the field's ability to integrate economics based arguments with management theories and concepts, such as information processing, expectancy-valence theory, to create a unique body of 
research with a strong focus on the firm and competitive interaction. Therefore, although strategic management in this period was heavily influenced by economics, researchers were able to develop new, unique theories for the field.

\section{Early Intermediate Methodologies}

Tremendous changes in the methodology of strategic management research occurred during this period. Schendel and Hatten strongly advocated that strategic management needed empirical research to show relationships between variables as "the conceptual development of the field has outstripped the research derived evidence available to support, deny or modify it" (1972: 101). Furthermore, they pointed out the need for strategy research to go beyond the inductive approach and conduct more deductive studies with "reliable data specifically collected to allow the development of testable answers to strategic questions" (1972: 102). Schendel and Hatten (1972) suggested that it was necessary for the field to build models, perform analyses, and develop theories. A landmark event that served to define the development of the field was a conference held in 1979 at the University of Pittsburgh organized by Dan Schendel and Charles Hofer. The purpose of the conference was threefold: (1) to describe and define the field of strategic management; (2) to critically examine the research methodologies and data sources presently in use; and (3) to suggest fruitful future directions (Schendel \& Hofer, 1979: vi). The push toward the new "strategic management" paradigm, and movement away from the more traditional "business policy" paradigm, was, therefore, markedly evident during this time. The adoption of the name "strategic management" signified the field's move towards a new paradigm, to become a more "scientific," empirically oriented research discipline (Schendel \& Hofer, 1979). Interest in theory building and research methodology began to proliferate among strategy researchers, as evidenced by the growing popularity of Robert Dubin's (1969) book, Theory Building.

Although normative, inductive case-based studies had dominated the early history of strategic management, positivistic, deductive empirical research became dominant during this period. Therefore, concern with explanation and prediction, rather than prescription, was strongly advocated by strategy scholars with the aim to elevate the field to a more rigorous, "scientific" academic discipline.

In this regard, IO economics has had an important effect on strategy research beyond theoretical influence, by encouraging strategy researchers to adopt the methodologies used in economics. Porter (1981: 617) holds that because IO economics research has developed "a strong empirical tradition built around the statistical analysis of populations of firms and industries," research on strategy would be able to supplement the more traditional case study with statistical methods. IO economics, as a sub-field of economics, utilizes the methodological framework of positive economics. In Essays in Positive Economics, Milton Friedman (1953) describes positive economics, unlike normative economics, as "in principle independent of any particular ethical or normative prescriptions," whereas "Its task is to provide a system of generalizations that can be used to make predictions about the consequences of any change in circumstances," and 
"Its performance is to be judged by the precision, scope, and conformity with experience of the predictions it yields" (1953: 4). In this regard, economics appears to bear substantial influence on both the theoretical, as well as methodological frameworks of strategic management, as it changed to become a more "scientific" and hence, more "respectable," academic discipline.

Concomitantly, the availability of commercial databases such as PIMS and COMPUSTAT provided strategic management researchers with convenient access to a large amount of firm level data. Moreover, researchers have also expended significant effort to construct data sets by means of large-scale surveys or detailed archival sources. Although the sample size in most studies was usually less than one hundred in the earlier period, a typical study now has at least hundreds of observations to as large as tens of thousands of observations (e.g., Chen \& MacMillan, 1992; Gimeno \& Woo, 1996). The use of more advanced statistics with the availability of statistical software packages and computers also enabled the use of large data sets. The increasing attention to the methodological issues helped to advance the research rigor in the strategic management field. For example, the early advocates of a more scientific approach to strategy research also introduced multivariate statistical analyses in their studies and emphasized the use of appropriate methods (e.g., Hatten, 1974; Hatten \& Schendel, 1977; Patton, 1976). The use of increasingly sophisticated methods in the field has been impressive [e.g., Gimeno \& Woo's (1996) use of panel data analysis; Keats \& Hitt's (1988) use of a causal modeling approach with time-ordered data; Chen \& MacMillan's (1992) use of logistic regression], signifying the ability and willingness of strategic management researchers to advance the field.

While IO economics emphasizes industry-level phenomena, strategic management is concerned with firm-level strategies. Application of the IO paradigms brought new and important foci to the strategic management field. However, building on the early work of Ansoff and others, there remained some missing pieces of the puzzle. Research has shown that some firms perform better than others in the same industry and/or within the same strategic group. This suggests firm-level phenomena are important. Furthermore, the competitive landscape for many industries began to change, particularly with the development of global markets (as opposed to domestic markets) (Hitt, Keats, \& DeMarie, 1998). Foreign firms entered domestic markets and, in some cases, armed with new ideas and strategies, began to capture significant market shares. Thus, strategic management scholars retrained their focus on the firm.

\section{A Swing Back Toward the Firm: Organizational Economics}

Unlike classical microeconomics that treats the firm as a production function (or "black box"), organizational economics is a sub-field of the economics discipline that ventures into the black box to unravel its inner structural logic and functioning. This primary interest in the "organization" (or the "firm") creates a strong affinity with strategic management. Two branches of organizational economics largely developed in the mid-1970s have since generated the most interest (and controversies) and studies in strategic management: transaction costs eco- 
nomics (Williamson, 1975, 1985) and agency theory (Fama, 1980; Jensen \& Meckling, 1976). TCE and agency theory's focus on the "firm" helps swing the strategic management pendulum further away from the industry level emphasis of the S-C-P paradigm and toward a firm level of analysis (see Figure 1).

TCE is largely built on Coase's (1937) critical insight on transaction costs as contained in his seminal article "The Nature of the Firm." Coase (1937) posited that organizations exist because the cost of managing economic exchanges between firms (transaction costs) is sometimes greater than that of managing exchanges within firms. To a lesser extent, agency theory draws on Coase's (1937) transaction costs concept, as well. However, the insight of Berle and Means (1932) on separation of ownership and control in modern U.S. corporations and the subsequent work on property rights (Alchian \& Demsetz, 1972) provided additional important building blocks for agency theory.

Continued rigorous development in organizational economics has provided important tools for strategic management researchers during this stage of the field's development. TCE and agency arguments have been applied in strategic management research in several substantive areas.

\section{Intermediate Theories}

Transaction costs economics. Williamson's (1975, 1985) formulation of transaction costs economics (TCE) seeks to explain why organizations exist. The basic premise of TCE is that markets and hierarchies are alternative governance mechanisms for completing transactions. To the extent that the price system fails to provide accurate and reliable market signals, hierarchies become a superior mechanism over arms-length market transactions. In the TCE framework, the unit of analysis is the firm-level dyadic transaction, wherein minimization of transaction costs is the efficient outcome. TCE logic is premised on a set of assumptions about human behavior and attributes of transactions that affect transactions between two firms: bounded rationality (developed by Simon, 1945), opportunism, uncertainty, small numbers, and asset specificity (Williamson, 1975, 1985). As a departure from IO economics research that is largely focused on industry structure that affects firm behaviors and performance, TCE-based research is built on the assumptions of human (or managerial) behaviors and attributes of transactions that affect modes of transaction (e.g., market versus hierarchy) and outcomes. Despite controversies around these assumptions [for example, see the debate between Donaldson (1990) and Barney (1991) or Hill's (1990) criticism on opportunism], strategic management researchers have applied transaction costs logic to examine a number of substantive topics [e.g., multidivisional form (M-form), hybrid forms of organization, and international strategy] to provide significant insights for the field.

The study of the M-form structure has a long tradition in the field of strategy that dates back to Chandler's (1962) seminal work. Among strategic management researchers, Williamson's TCE provides the predominant theoretical rationale to explain the increasing and wide adoption of M-form. A majority of empirical studies in the strategic management have found some evidence that the M-form is generally associated with higher performance (e.g., Hill, 1985; Hoskisson \& 
Galbraith, 1985; Hoskisson, 1987; Hoskisson, Harrison, \& Dubofsky, 1991). More recently, strategy researchers have provided an important clarification regarding the link between $\mathrm{M}$-form and performance by pointing out that $\mathrm{M}$-form efficiency is dependent on internal contingencies (Hill \& Hoskisson, 1987; Hill, Hitt, \& Hoskisson, 1992; Hoskisson \& Johnson, 1992). These researchers suggest that different types of transaction costs efficiency are related to different strategies (vertical integration, related and unrelated diversification). For instance, related diversification is associated with the economies of scope benefits, whereas unrelated diversification chiefly benefits from financial economies of the internal capital market. More specifically, Hill et al. (1992) further specify the structures, whereby these kinds of benefits can be achieved. To enjoy the benefits from vertical integration or related diversification, an internal cooperative structure is needed; on the other hand, to capture the benefits from unrelated diversification, an internal competitive structure is required. Hoskisson, Hill, and Kim (1993) have comprehensively reviewed $\mathrm{M}$-form research in strategic management.

Another topic where TCE is fruitfully applied is the hybrid form of organization. "Hybrids" refer to the various organizing modes between the two polarities of markets and hierarchies, such as joint ventures, franchising, and licensing. With the recent increase in hybrid forms of organization, Williamson (1991) attempted to incorporate the hybrid forms into his framework as special cases along the continuum of markets and hierarchies. Kogut (1988) posits that there are two internal conditions that characterize a joint venture: joint ownership (and control) and mutual commitment of resources. Also, there are two situational characteristics most appropriately suited for joint ventures: asset specificity and high uncertainty in performance specification and monitoring. Joint ventures provide a "mutual hostage position," whereby uncertainty with regard to opportunistic behaviors can be resolved. Consistent with TCE arguments, Hennart (1988: 364) points out that joint ventures are "a device to bypass inefficient markets for intermediate inputs" because the presence of intermediate market inefficiencies is a necessary condition for the establishment of joint ventures.

Perhaps owing to the additional transactional concern in international operations, a substantial amount of recent empirical work applying TCE to strategic management focuses on international market entry or involve an international context [e.g., Hennart \& Park's $(1993,1994)$ studies on Japanese entries in the United States and Dyer's $(1996,1997)$ studies comparing Japanese and U.S. automotive manufacturers]. Together with internalization theory that also uses transaction costs logic, and was independently developed by a group of international business researchers (e.g., Buckley \& Casson, 1981; Rugman, 1981), the use of TCE has substantially increased our understanding of the choice of international modes of entry or operations (e.g., Hill \& Kim, 1988).

Agency theory. Agency theory, as developed in the financial economics literature (e.g., Jensen \& Meckling, 1976; Fama \& Jensen, 1983), has attracted the attention of many strategic management researchers leading to a large number of studies over the last two decades. Primarily drawing on the property rights literature (e.g., Alchian \& Demsetz, 1972) and TCE, agency theory posits that due to "separation of ownership and control" in modern corporations, there is often a 
divergence of interests between shareholders (principals) and managers (agents). Agency theory assumes that human beings are boundedly rational, self-interested, and opportunistic (Eisenhardt, 1989a), and therefore managers will seek to maximize their own interests even at the expense of the shareholders. According to agency theory, a firm is a nexus of contracts and as such, the basic unit of analysis in agency theory is the contract. Agency theory helps swing the pendulum back further toward a firm level focus because it seeks to enter the "black box" to examine causes and consequences of agency conflict between shareholders and managers, and the effectiveness of various governance devices designed to mitigate the conflict. Therefore, the theoretical concern of agency theory is more at a firm level of analysis than TCE.

Strategy researchers have applied agency theory to a number of substantive topics, including innovation, corporate governance, and diversification; and the results are, in general, consistent with the prediction of agency theory. Because managers' firm-specific investments in human capital are not diversifiable, they may have the incentive to pursue firm diversification, especially unrelated diversification, in order to diversify their employment risk, so long as firm profitability does not suffer too excessively (e.g., Hoskisson \& Turk, 1990). Because firm size and executive compensation are highly correlated (e.g., Tosi \& Gomez-Meija, 1989), managers also have an additional incentive to increase the size of the firm by diversification to obtain higher levels of personal compensation. Hoskisson and Hitt's (1990) review of diversification research provides a detailed discussion on the relation between agency theory and diversification.

Internal governance mechanisms such as board composition (e.g., Baysinger \& Hoskisson, 1989; Baysinger, Kosnik, \& Turk, 1991; Hill \& Snell, 1988; Zahra \& Pearce, 1989), ownership structure (e.g., Bethel \& Liebeskind, 1993; Hill \& Snell, 1988; Hoskisson \& Turk, 1990; Kosnik, 1990) and executive compensation (e.g., Gomez-Meija, 1994; Hoskisson, Hitt, Turk, \& Tyler, 1989; Tosi \& GomezMeija, 1989) may be used to help align the interests between shareholders and managers. External governance devices, such as the market for the corporate control, become more relevant (active) when internal governance devices are unable to mitigate agency costs (Johnson, Hoskisson, \& Hitt, 1993; Walsh \& Kosnik, 1993; Walsh \& Seward, 1990). However, there is no perfect governance mechanism that fully eliminates agency conflicts. Tradeoffs may influence a firm's level and type of diversification (Baysinger \& Hoskisson, 1989). Moreover, managers are able to devise means to reduce the effectiveness of governance devices. For instance, the adoption of anti-takeover amendments, such as poison pills (e.g., Mallette \& Fowler, 1992; Sundaramurthy, 1996), can reduce the threat of the market for corporate control.

Agency conflicts may also affect corporate innovation. Investments in R\&D create higher levels of risk for the managers; consequently, risk-averse managers are reluctant to engage in innovative activities, which, in turn, results in loss of competitiveness and lower performance (Hoskisson, Hitt, \& Hill, 1993). Baysinger and Hoskisson (1989) found a negative relationship between diversification strategy and R\&D investment. As a further support of the argument that firm innovation is affected by managerial opportunism, Kochhar and David 
(1996) found that institutional ownership (as a governance device) is positively related to firm innovation. Thus, institutional owners ensure that managers make proper investments in innovation to maintain the firm's competitiveness.

Instead of industry structure variables, such as market concentration or scale economies that determine firm behaviors and performance as postulated by IO based research, the principal drivers of firm strategy and performance in organizational economics are managerial motives (opportunism) and capabilities (bounded rationality), information asymmetry, contracts enforcement, performance evaluation, and the transaction relationship between two parties (firms in TCE and principal and agent in agency theory). Thus, the main concerns of strategic management research based on organizational economics are vastly different from those based on IO economics. Gradually, strategy research was moving back to the direction of examining how the firms' internal mechanisms and attributes influence firm strategy and performance.

\section{Intermediate Methodologies}

Microeconomics has been driven by a concern for refining its internal logic and has become increasingly more mathematically oriented. Although strategic management has striven to attain rigorous scientific standards, its study domain has to be relevant to actual business operations. In this regard, strategic management researchers during this period were attracted to organizational economics because it focused on institutional details and human (managerial) action as opposed to mathematical displays (Rumelt et al., 1994). This choice is exemplified by strategic management researchers adoption of positivist agency theory (e.g., Jensen \& Meckling, 1976), instead of the more mathematical, normative principal-agent theory.

Nevertheless, research based on either TCE or agency theory encounters the problem of unobservables (Godfrey \& Hill, 1995), which presents significant challenges for empirical research. As Godfrey and Hill (1995) contend, some of the key variables in organizational economics, such as opportunism and the degree of divergent interests, obviously suffer from measurement unobservability. Reviewing the literature on the relationship between agency motives and diversification, Hoskisson and Hitt (1990), also note that research in this area has been limited because (1) managers are unlikely to admit that agency motives are present in decision-making, and (2) unambiguous indicators of the effects of governance mechanisms on firm behaviors are difficult to isolate. Consequently, researchers have to rely on "more speculative theory and indirect research on governance structure mechanism," such as ownership structure and executive compensation (Hoskisson \& Hitt, 1990). Such methodological problems pose significant challenges to strategic management researchers and also create controversy among researchers holding different assumptions about the nature of human motives (an excellent example is the debate regarding TCE between Ghoshal \& Moran, 1996, Williamson, 1996, and Moran \& Ghoshal, 1996).

There was increasing adoption of sophisticated research methods during this period. For instance, the application of structural equation modeling in strategic management studies has become increasingly common, as exemplified in work by 
Hoskisson, Johnson, and Moesel (1994) and Hitt, Hoskisson, Johnson, and Moesel (1996). The growing availability of large databases, as well as researchers' effort in collecting data from other archival sources and large-scale surveys, have contributed to the increasing level of methodological sophistication used in strategic management research.

While transaction costs theory and agency theory contributed substantially to our understanding of strategic management, there were still missing pieces of the puzzle. Some argued that there were idiosyncratic characteristics of firms that contributed to their competitive advantage (e.g., Barney, 1991; Wernerfelt, 1984). For example, some firms more effectively manage transaction costs, while others are able to respond to competitors' actions more effectively than others. The heterogeneity among firms in the same industry (or strategic group), then, is of importance. The primary differentiation of firms is in their resources, tangible and intangible. The importance of resources, however, was not a new concept. As Penrose (1959) argued, firms were collections of productive resources, and the heterogeneity of resources provides firms with their unique characters. Thus, the field was coming full circle, back to its roots with a renewed focus on firms' idiosyncratic resources. Importantly, the renewed focus on resources was coupled with scholarly work integrating the environmental characteristics (IO economics) and firm specific resources to examine and understand strategic management (i.e., Dess, Gupta, Hennart, \& Hill, 1995). The integration of these views is exemplified in Grimm and Smith's (1997) action-based model of organizational evolution. Next, we examine the renewed emphasis on idiosyncratic firm resources.

\section{Back Toward the Starting Point: The Resource-Based View}

Recently, the popularity of the resource-based view of the firm has once again returned our focus inside the black box of the firm (see Figure 1). The significance of the RBV was recognized when Birger Wernerfelt's (1984) "A Resource-based View of the Firm" was selected as the best 1994 paper published in the Strategic Management Journal. The RBV emerged as "an important new conceptualization in the field of strategic management" and is "one of the most important redirections of the (content of) strategy research in this decade" (Zajac, 1995: 169). Theoretically, the central premise of RBV addresses the fundamental question of why firms are different and how firms achieve and sustain competitive advantage. Research sub-streams also focus on specific types of resources inside a firm, such as strategic leadership and tacit knowledge. Methodologically, the RBV also has helped the field reintroduce inductive, case-based methods focused on a single or a few firms into the research to complement deductive, large-sample methods. In this section, we trace how the pendulum is swinging back to the starting point.

\section{Current Theories}

Resource-based view of the firm. The resource-based view of the firm is not new. Its footprints can be found in early management works. The relationship between a firm's special competencies (deploying its resources) and firm perfor- 
mance was embedded in some classic management treatises. For instance, Selznick's (1957) idea of an organization's "distinctive competence" is directly related to the RBV. Also, Chandler's (1962) notion of "structure follows strategy," as well as Andrew's (1971) proposal of "an internal appraisal of strengths and weaknesses, led to identification of distinctive competencies." Additionally, Ansoff's (1965) definition of synergy as "one internally generated by a combination of capabilities or competencies" is related to the RBV.

However, the founding idea of viewing a firm as a bundle of resources was pioneered in 1959 by Penrose in her theory of the growth of the firm. Penrose viewed the firm as a collection of productive resources- "[A] firm is more than an administrative unit; it is also a collection of productive resources the disposal of which between different uses and over time is determined by administrative decision" (1959: 24). And she defined resources as "the physical things a firm buys, leases, or produces for its own use, and the people hired on terms that make them effectively part of the firm" (1959: 67). Penrose argued that it is the heterogeneity, not the homogeneity, of the productive services available or potentially available from its resources that gives each firm its unique character. The notion that firms attain a unique character by virtue of their heterogeneous resources is the basis of RBV. Penrose also related the interaction between material and human resources to firm performance. Such a resource-performance linkage is a salient issue in strategic management.

Since the early 1980s, researchers have been developing and defining resource-based concepts, and seeking to relate how resources can give rise to firm competitive advantage. Wernerfelt (1984) suggested that evaluating firms in terms of their resources can lead to insights that differ from the traditional perspective. A firm's resources are defined as tangible and intangible assets which are tied semi-permanently to the firm. In an analogy to entry barriers, Wernerfelt examined the relationship between resources and profitability in terms of resource position barriers, proposing that a first mover advantage is an attractive resource that should yield high returns in markets where the resource in question dominates. Moreover, in an analogy to the growth-share matrix, a resource-product matrix was used as a way to examine the balance between the exploitation of existing resources and the development of new ones. Though Wernerfelt's (1984) article was rather abstract, it opened a new ground for later researchers on which to build (Wernerfelt, 1995).

Extending Wernerfelt's (1984) work, researchers attempted to explain more specifically how differences in firms' resources realized superior firm performance. Based on the assumption of resource heterogeneity, Rumelt (1984) explained that firms may start as homogeneous, but with "isolating mechanisms," they become differentiated such that their resources cannot be perfectly imitated. Barney (1986a) suggested that resource factors differ in their "tradeability," where a tradeable factor is one that can be specifically identified and its monetary value determined via a "strategic factor market." Dierickx and Cool (1989) suggested that resources can be differentiated as either asset flows or asset stocks. They explained economic rent sustainability in terms of resources with limited strategic 
substitutability by equivalent assets and time compression diseconomies for firms trying to imitate resources of another firm.

Another group of researchers focused on examining specific resources which give rise to sustainable competitive advantages. The resources they examined included: response lags (Lippman \& Rumelt, 1982), routines (Nelson \& Winter, 1982), functionally based distinctive competencies (Hitt \& Ireland, 1985, 1986; Hitt, Ireland, \& Palia, 1982; Hitt, Ireland, \& Stadter, 1982; Snow \& Hrebiniak, 1980), unique combination of business experience (Huff, 1982; Prahalad \& Bettis, 1986; Spender, 1989), organizational culture (Barney, 1986b; Fiol, 1991), invisible assets that by their nature are difficult to imitate (Itami, 1987), organizational learning (Teece, Pisano, \& Shuen, 1997), entrepreneurship (Nelson, 1991; Rumelt, 1987), and human resources (Amit \& Schoemaker, 1993), among others.

In 1991, Barney presented a more concrete and comprehensive framework to identify the needed characteristics of firm resources in order to generate sustainable competitive advantages (Barney, 1991). Four criteria were proposed to assess the economic implications of the resources: value, rareness, inimitability, and substitutability. Value refers to the extent to which the firm's combination of resources fits with the external environment so that the firm is able to exploit opportunities and/or neutralize threats in the competitive environment. Rareness refers to the physical or perceived physical rareness of the resources in the factor markets. Inimitability is the continuation of imperfect factor markets via information asymmetry such that resources cannot be obtained or recreated by other firms without a cost disadvantage. Finally, the framework also considers whether the organizations are substitutable by competitors.

One of the criticisms of Barney's framework is that it does not account for bundles of resources; the framework treats resources as singularly distinct factors (Black \& Boal, 1994). To remedy this, some researchers proposed that resources are nested by factor networks that have specific interrelationships (e.g., Black \& Boal, 1994; Grant, 1991) and that there is a need to examine the dynamic interrelationships among the resources. Robins (1992) argued that these firm specific relationships generate quasi-rents because the tradable factors have their value bid away. Amit and Schoemaker (1993) expanded the framework in which such value that included the sub-dimensions of an external link overlapping with strategic industry factors and internal complementarity. Rareness was expanded to include scarcity and low tradability. Inimitability was divided into inimitability and limited substitutability. And organization configuration was specified as appropriability and durability.

Recently, the research on RBV has become further specialized. First, rigidities in acquiring resources may be different from the rigidities in shedding resources (Montgomery, 1995), and some resources may have negative value by creating core rigidities (Leonard-Barton, 1992). Second, a controversy has evolved concerning the potential of the RBV to be a theory of the firm. Conner (1991) compared RBV to five fundamental approaches used in industrial organization economics: perfect competition model, Bain-type IO, the Schumpeterian and Chicago Schools of economics, and transaction cost economics. Mahoney and Pandian (1992) suggested the distinctiveness of the RBV compared to the orga- 
nizational economics paradigms, including evolutionary economics, transaction cost economics, property rights theory, and positive agency theory. Both Conner and Mahoney and Pandian concluded that RBV may form the kernel of a unifying paradigm for strategic management research. RBV provides a framework for increasing dialogue between scholars from different disciplines within the conversation of strategic management. This is demonstrated by Oliver (1997) who tried to extend the boundary of the resource-based view of the firm to incorporate the institutional perspective to explain variation in firm performance. Lastly, sub-streams are emerging from the RBV, such as strategic leadership and the knowledge-based view of the firm, as elaborated below.

Strategic leadership and strategic decision theory. A potentially unique resource is a firm's strategic leaders. As such, strategic leadership has developed into a significant stream of strategic management research (Finkelstein \& Hambrick, 1996). Strategic leadership research focuses on individuals (e.g., CEO or division general managers), groups (e.g., top management teams) or other governance bodies (e.g., board of directors).

Studying the role of top executives has been a historical topic of interest in the management literature. Fayol (1949) proposed the major managerial actions as planning, organizing, coordinating, commanding, and controlling. Barnard (1938) and Selznick (1957) suggested that the top management job is to establish and convey "organizational meaning" and maintain institutional integrity. In his book The Nature of Managerial Work, Henry Mintzberg (1973) classified ten managerial roles into three categories: interpersonal, informational, and decisional. Mintzberg's general portrayal of managerial work was confirmed in later studies (Kotter, 1982; Tsui, 1984). As proposed by March and Simon (1958), top managers are embedded in a situation of ambiguity, complexity, and often experience information overload. In such circumstances, the decision maker's personal frame of reference, experiences, education, functional background, and other personal attributes have significant effects on their decisions and actions. Thus, the multiplicity of top managers' roles, as well as the "bounded rationality" of these managers, served as a basis for research on the effects of strategic leaders on the form and fate of their organizations.

Kotter's (1982) The General Managers helped to foster a formal stream of strategic leadership research. Kotter posited that differences in managers' behavior may be traceable to differences in their personal and background characteristics. Shortly thereafter, Hambrick and Mason (1984) presented a more formal theoretical framework based on the upper echelon perspective, proposing that senior executives make strategic choices on the basis of their cognitions and values. They argued that an organization becomes "a reflection of its top managers."

Following Hambrick and Mason, a substantial number of academic and applied studies on top executives and their organizations were conducted. Empirical evidence of strategic leaders' effects on organizational outcomes is numerous. Organizational performance was found to be associated with: executives' past performance record (Pfeffer \& Davis-Blake, 1986; Smith, Carson, \& Alexander, 1984), top management team size, composition, and tenure (Haleblian \& 
Finkelstein, 1993; Murray, 1989; Smith et al., 1994). Apart from the direct effects of strategic leaders on organizational performance, top management characteristics were also found to be related to firm strategies and structures (Helmich \& Brown, 1972; Miller \& Droge, 1986). These indirect effects implied that the relationship between strategic leaders and organizational performance may depend on some contingency factors.

Hambrick and Finkelstein (1987) outlined the concept of "managerial discretion" which refers to the latitude of action and is a function of "(1) the degree to which the environment allows variety and change, (2) the degree to which the organization is amenable to an array of possible actions and empowers the chief executive to formulate and execute those actions, and (3) the degree to which the chief executive personally is able to envision or create multiple courses of action" (p. 379). Empirical attempts were made to identify high- and low-discretion industries (Finkelstein \& Hambrick, 1990; Haleblian \& Finkelstein, 1993; Hambrick \& Abrahamson, 1995). Managerial discretion, which links the individual characteristics of strategic leaders with organizational and environmental factors, is believed to be a fruitful area for future strategic leadership research (Finkelstein \& Hambrick, 1996).

A primary catalyst for research on managerial discretion was John Child's (1972) work on strategic choice. Child, in effect, argued that managers had the discretion to make strategic choices; firm outcomes were not largely dictated by external environmental conditions. This led to debates of environmental determinism versus strategic choice (e.g., Hitt \& Tyler, 1991; Hrebiniak \& Joyce, 1985). This research served as a catalyst to work on the fit between the environment and firm strategy (i.e., Miller \& Friesen, 1984). It also spawned a more behavioral or cognitive perspective of strategic decision making. This perspective is exemplified in the work by Huff and others on cognitive mapping (e.g., Barr, Stimpert, \& Huff, 1992; Huff, 1990; Markoczy \& Goldberg, 1995) and in the work by Hitt and colleagues using policy capturing (e.g., Hitt, Dacin, Tyler, \& Park, 1997; Hitt \& Tyler, 1991). Speed of strategic decision making has been addressed by Eisenhardt (1989b).

Knowledge-based view of the firm. The knowledge-based view (KBV) of the firm is an extension of the RBV by conceptualizing firms as heterogeneous, knowledge-bearing entities. Viewing a firm from a knowledge-based perspective was sparked by Michael Polanyi's (1966) assertion, "We can know more than we can tell" (p. 4). Polanyi classified knowledge into two categories: explicit or codified knowledge which refers to knowledge that is transmittable in formal, systematic language; and tacit knowledge which has a personal quality and, thus, is difficult to formalize and communicate. Later, Zander and Kogut (1995) operationalized the construct of knowledge into five dimensions: codifiablity, teachability, complexity, system dependence, and product observability.

Building on Polanyi's idea, Kogut and Zander (1992) presented a contrast between the knowledge-based perspective and the contracting perspective. They argued that the assumptions of selfishness are not a necessary premise for shirking or dishonesty. Instead, they view firms as a repository of capabilities in which individual and social expertise is transformed into economically valuable prod- 
ucts. They posit that "firms exist because they provide a social community of voluntaristic action structured by organizing principles that are not reducible to individuals" (p. 384). This means that by its tacitness and social complexity, a firm's stock of knowledge is an important determinant of its competitive advantage. Such a conceptualization of firms as bearers of tacit, social, and pathdependent organizational knowledge created a new paradigm relative to the conceptualization of the contractual approaches (Foss, 1996).

Such a notion that "firms do better than market" (Kogut \& Zander, 1992) is supported by Nonaka (1994) who posited that "the theory of organizational knowledge is a basic theory for building a truly 'humanistic' knowledge society beyond the limitation of mere economic rationality" (p. 24). Conner and Prahalad (1996) compared knowledge-based predictions of organizational modes with opportunism-based ones. They argued that when opportunistic potential is too low to justify a firm, a different mode of organizing is then selected according to the knowledge-based perspective. While the opportunism-based approach anticipates a firm, the KBV suggests whether a firm, joint venture, or market contracting will be optimal. Kogut and Zander (1996) elaborated that the KBV has an economic value over market transactions when identity leads to social knowledge that supports coordination and communication. This suggests that the KBV is a behavioral approach that predicts the superiority of firms over markets.

Research on the KBV is often process-oriented. For instance, Cohen and Levinthal (1990) proposed a new perspective on learning and innovation. They introduced a term "absorptive capacity" that refers to the ability of a firm to recognize the value of new, external information, assimilate it, and apply it to commercial ends. Absorptive capacity is dependent on a firm's level of prior related knowledge. As such, ease of learning is affected by the degree to which an innovation is related to this pre-existing knowledge. Pisano (1994) also suggested there is no one best way to learn, but different approaches may be required in different knowledge environments. Nonaka (1994) focused on the knowledge creation process. He explained that the interactive amplification of tacit and explicit knowledge through socialization, combination, externalization, and internalization, knowledge held by individuals, organizations, and societies can be enlarged and enriched simultaneously. As such, firms have capabilities, if used to create knowledge which leads to commercial value, and such knowledge capabilities are hard to duplicate. Finally, Lei, Hitt, and Bettis (1996) integrate the $\mathrm{RBV}$ and KBV by arguing that core competencies only maintain value through continuous development. They suggest that the dynamic qualities of competencies are developed through meta-learning; that is, the capability to learn continuously.

\section{Current Methodologies}

Because the RBV emphasizes the idiosyncratic nature of a firm's resources and capabilities, empirical testing of the resource-based theory faces great challenges. Nonetheless, empirical research on this topic is beginning to develop.

Because valuable, rare and inimitable resources are usually intangible in nature and intangible resources are more difficult to measure (Godfrey \& Hill, 1995), RBV researchers have used proxies as measures of intangible constructs. 
For example, Kochhar, Hitt, and Bierman (1996) used human capital leverage as a proxy for employee skills and capabilities, and the number of large corporations from the top 250 firms that served as the clients of the law firms to proxy for firm's reputation. This measure was validated by a survey evaluating the reputation of the top 100 law firms. In their study of movie studios, Miller and Shamsie (1996) used former investments in complex, large-skill film projects as a proxy for the complex set of team, coordinative and integrative knowledge-based resources. However, as argued by Godfrey and Hill (1995), it is by construction impossible to assess the degree of unobservability of an unobservable, and, by definition, inimitable resources are unobservable. Therefore, unobservability poses a substantial measurement challenge to RBV researchers. Proxies may not be valid measures for the underlying constructs.

To supplement the proxies of resource-based constructs, Henderson and Cockburn (1994) used both quantitative questionnaires and qualitative interviews, as well as multiple informants, to increase the validity and reliability of the measures of organizational competence. In their study of the evolution of technological capabilities, Stuart and Podolyny (1996) developed a network-analytical approach to quantify the evolution of firms' technological positions. Such an approach permits graphical and quantitative assessment of firms' search behavior, and enables firms to be positioned and grouped according to the similarities in their innovative capabilities.

Both multi-industry studies (Markides \& Williamson, 1994; Robins \& Wiersema, 1995) and single industry studies (Almeida, 1996; Kochhar et al., 1996; Miller \& Shamsie, 1996) of the resource-based view have been conducted. Single industries provide a particularly important context for examining resources critical to the industries and markets in question. However, the tradeoff of single-industry studies is the generalizability of the empirical findings (Dess, Ireland, \& Hitt, 1990).

Events studies from finance have been used to examine the effects of executives' strategic decisions on a large variety of issues. However, McWilliams and Siegel (1997) argued that this methodology needs to be appropriately applied with theory that clearly shows a connection to stock market evaluation.

Rather than adopting the received method of large-scale data collection approaches, the case study methodology may be appropriate for the RBV research because it can provide much richer information about the firms' idiosyncrasies. More sophisticated case methodologies have been adopted by Collis (1991), Doz (1996), Hitt, Harrison, Ireland, and Best (1998) and Kotha (1995), including detailed field-based case studies, collection of both archival and interview data, and in-depth case studies, respectively.

In summary, the RBV of the firm has provided important new insights into corporate strategy (Barney, 1991; Peteraf, 1993). However, there has been limited empirical research testing the theory (Farjoun, 1994). Empirical research on resource-based corporate strategy has been particularly difficult because key concepts such as tacit knowledge or capabilities resist direct measurement (Robins \& Wiersema, 1995). Nonetheless, RBV researchers have already made great strides in overcoming these empirical problems. Attempts to quantify empirically 
the nature and effects of resource-based constructs offer a fruitful avenue for future research.

\section{Future Directions}

The greatest challenge, and at the same time the most interesting aspect, of strategic management as a scholarly discipline is the ever-evolving nature of its research. The fluidity of many strategic issues requires strategy researchers to keep advancing the extant body of knowledge. As we approach the new millenium, the new competitive landscape, constituted by rapid technological changes and increasing globalization, will continue to pose different research questions for strategic management researchers (Bettis \& Hitt, 1995). Strategic researchers will be increasingly challenged to respond to frequent, discontinuous changes and provide answers to new problems. In fact, the results of strategic management research will become increasingly important for current executives and in educating future executives (e.g., MBA programs). As such, the quality of this research and its ability to provide answers to critical strategy questions takes on a new urgency with the highly dynamic competitive landscape (Hitt et al., 1998).

Because the nature of strategy problems cannot easily be framed within a fixed paradigm, strategic management is necessarily a multi-paradigmatic discipline, requiring varied theoretical perspectives and methodologies. Furthermore, as Rumelt et al. contended, "Strategic management as a field of inquiry is firmly grounded in practice and exists because of the importance of its subject" (1994: 9). As a result, because of the practical nature of the field, strategic management is likely to continue to flourish by using a wide variety of theoretical perspectives and methodologies in order to help explain firm performance.

\section{Theories}

From an IO economics perspective, mobility barriers or market positions are the critical sources of competitive advantages that lead to superior performance. Organizational economics is more concerned with devising appropriate governance mechanisms or contracts to help reduce transaction or agency costs. However, the advance of RBV has refocused the field of strategic management on the firm's internal characteristics and views firms' internal resources as the source of competitive advantage. While all three theoretical perspectives have significantly advanced our understanding of the sources of competitive advantages and hence firm performance, the sustainability of firms' competitive advantages has increasingly become an important question, because the new competitive landscape forces firms to continue to evaluate the sustainability of their positions (Bettis \& Hitt, 1995; Hitt, 1998; Porter, 1996). Consequently, some strategic management researchers are advocating the importance of dynamic core competencies (Lei et al., 1996) or the understanding of firms' market positions from a dynamic theoretical perspective (Porter, 1991). The dynamic nature of firm resources, or more generally firms' strategic flexibility (Hitt, 1998; Hitt, Keats, \& DeMarie, 1998; Sanchez, 1995), makes the study of the sources and sustainability of competitive advantages an important research objective. As valuable knowl- 
edge and resources become transient, organizational learning (Nonaka, 1991; Nonaka \& Takeuchi, 1995), by definition a dynamic process, is likely to be incorporated into many theoretical models for the study of strategy.

Rapid change in technology and the rise of the information age means that the nature and pace of firm competition are likely to be different (Brown \& Eisenhardt, 1995; Hitt, Keats, \& DeMarie, 1998; Stimpert \& Duhaime, 1997). Oftentimes, competitors strive to overcome others' technological capabilities, rendering the current technological standard obsolete. Firms are less inclined to attempt to break competitors' mobility barriers; instead, an increasing number of firms are trying to develop a new game. Technological discontinuities (Tushman \& Andersen, 1986) and hypercompetition (D'Aveni, 1994) are becoming the norm in the new competitive landscape.

Parallel to the rapid technological change is the increased level of globalization. As firms compete in the global market, the competitive resources and positions of firms become more complex. Hence, it is more difficult for strategic management researchers to examine research questions using a single theoretical framework. Increasingly, researchers are integrating multiple theoretical frameworks to explain complex international strategic issues (e.g., Hitt, Hoskisson, \& Kim, 1997). The sustainability of competitive resources obtained from the global market may represent a different dimension for firm competition. These resources can be obtained from global level learning by means of foreign subsidiaries or through strategic alliances. Cooperative strategies (Osborn \& Hagedoorn, 1997), especially network strategy (Gomes-Casseres, 1996) on an international scale, continue to shape the trajectory, nature and pattern of business competition. Challenging issues such as international alliance partner selection (Dacin, Hitt, \& Levitas, 1997) and acquisition of new knowledge or technology (Hitt, Ireland, \& Hoskisson, 1997; Singh, 1995) are likely to capture the attention of many strategic management researchers in the near future.

Related to the issue of globalization is the importance of the institutional context of international research. There is no theoretical work nor empirical findings suggesting that the existing body of knowledge, largely obtained in the context of the United States, is equally applicable in other countries. Boyacigiller and Adler (1991) expressed similar concerns about the applicability of organization science's theories and research in a global context. In a similar vein, firm strategies, organization structures, and governance mechanisms successfully pursued and implemented in a particular institutional context may not achieve the same outcomes in another institutional context. The universality of specific competitive advantages increasingly will be called into question. These issues are explored in a Special Research Forum on Strategies in Emerging Economies of the Academy of Management Journal (Hoskisson, Eden, Lau, \& Wright, in press). Certainly, more research is required that accounts for the institutional differences among geographic or cultural environments. For instance, Porter (1998b) has recently suggested that geographic clusters of interrelated firms (e.g., Silicon Valley; Pouder \& St. John, 1996) are magnets for foreign investment.

In contrast to agency theory, a new approach to understanding top management motivation and actions is stewardship theory (Davis, Schoorman, \& Donald- 
son, 1997). Stewardship theory suggests that managers are "stewards" of the firm's assets and are not motivated by individual goals. The manager as steward believes there is greater utility in collective (organizational) behavior and, thus, seeks to attain the goals of the organization. According to Davis et al. (1997), stewardship theory is not in juxtaposition to agency theory; rather it helps explain some managerial behavior in addition to agency theory. Thus, it helps provide a more complete understanding of managerial behavior by adding to our knowledge. However, "because stewardship theory is relatively new, its theoretic contribution has not been adequately established" (Davis et al., 1997, p. 21). Therefore, more theoretical and, importantly, more empirical research is needed to understand stewardship theory's specific theoretical contribution to strategic management and to test its theoretical propositions through empirical research.

Finally, Dess et al. (1995) called for more integrating research across two or more levels of strategy. Specifically, they argued that most strategy research focuses on a single level of strategy, international, corporate-level or businesslevel strategy. However, most large multibusiness organizations formulate and implement strategies at all three levels. We understand little about the interaction of different strategies at different levels. Certainly, they are linked to sets of resources and may be highly interrelated. For example, a firm that is moving into new international markets may have to implement an integrated low cost-differentiation business strategy to be competitive in global markets (Hitt, Ireland, \& Hoskisson, 1997). Dess et al. (1995) suggest that soon such integrative research may not represent a choice but rather be required for strategic management scholars. Such integration will require examining multiple theoretical perspectives along with the focus on multiple levels. To this can be added the need to examine the differential effects of the environment on large and small firms and the variance in competitive actions and responses (strategies employed) by size of the firm (Dean et al., 1998). Thus, future research of this nature will be highly complex, but also valuable.

Therefore, the field of strategic management will likely experience increasing integration of multiple theoretical paradigms. Explanations of the future trends also suggest a balance between internal and external explanations of the complex relationships in the new competitive landscape. To meet this challenge, strategic management researchers must continue to advance existing theories, regardless of the complexity. The fruitfulness of the discipline depends to a large extent on the success of meeting this challenge.

\section{Methodologies}

In light of the future complexity and variety of the issues facing strategic managment researchers, the methodologies used will likewise reflect a similar level of complexity. Depending on the research questions under study, we have witnessed the use of a wide variety of methodological tools such as event studies (e.g., Wright \& Ferris, 1997), event history analysis (e.g., Blodgett, 1992; Zajac \& Westphal, 1996), structural equation modeling (Hitt et al., 1996; Hoskisson et al., 1994), multi-dimensional scaling (e.g., Hitt, Nixon, Hoskisson, \& Kochhar, in press; Stuart \& Podolny, 1996), panel data analysis (e.g., Gimeno \& Woo, 1996), 
repertory grid (e.g., Ginsberg, 1988, 1989), cognitive mapping (e.g., Barr, Stimpert, \& Huff, 1992), and policy capturing (e.g., Hitt \& Tyler, 1991; Hitt et al., 1997). More recently, newer methods, such as network analysis (e.g., Gulati, 1995), heterogeneous diffusion models (e.g., Greve, 1996), and sample selection models (e.g., Barnett, Greve, \& Park, 1994) are being employed in strategic management research. As indicated by Hitt, Gimeno, and Hoskisson's (1998) recent review, different types of research methods are likely to be adopted by strategy researchers tackling different research questions.

The choice of quantitative methods or qualitative methods has been the subject of controversy and the apparent "dominance" of more quantitative-based methodological tools in the development of the field does not mean that these tools are applicable to all research questions. The recent advance of the RBV has posed new challenges regarding the use of quantitative methods, although some researchers have attempted to use coarse-grained measures (e.g., Chatterjee \& Wernerfelt, 1991; Kochhar et al., 1996; Miller \& Shamsie, 1996) or large sample data (e.g., Markides \& Williamson, 1994) to test RBV arguments. However, due to the intangible nature of important firm resources, researchers have used detailed field-based study, longitudinal case studies, outlier samples, and case surveys (e.g., Collis, 1991; Doz, 1996; Hitt et al., 1998; Larsson, 1993) to test RBV hypotheses.

Because of the challenges posed by new research questions, we will likely see the continued use of different research methods in the field of strategic management. The research question and context should dictate the choice of the appropriate research methods. In all likelihood, results obtained from different methods have the potential to enrich our understanding of the problems and generate new insights regarding the issues. Moreover, the integration of quantitative and qualitative methodological tools (e.g., Hitt, Gimeno, \& Hoskisson, 1998; Judge \& Zeithaml, 1992) is likely to be a fruitful course, especially because of the reemphasis on issues inside the firm through the RBV.

\section{Conclusion}

Looking back at the past several decades of development in strategic management, we have seen that each pendulum swing has taken us to new theoretical paradigms and methodological approaches. Perhaps more importantly, the pendulum swings enlarge the domain of the field and lead us to address a wider variety of research questions. Later research paradigms have benefited from earlier ones, thereby enriching the field's total body of knowledge. These pendulum swings help accumulate newer theories and methodologies.

Although the advent of the RBV apparently takes the field back to our starting point, the level of theoretical and methodological sophistication and maturity currently exhibited underscores the extent that the field has advanced over the last several decades. Research based on IO and organizational economics continues to progress, but is mostly tracking the path of strategic management. With each swing of the pendulum, the field of strategic management has made significant progress and will continue to flourish into the next millenium. 


\section{Notes}

1. Gordon and Howell (1959: cf. Porter \& McKibbin, 1988; Schendel \& Hofer, 1979), in the Ford Foundationsponsored study of business school curriculum, recommended that there should be a capstone course in "business policy" that provides the students with an opportunity to integrate what they have learned in the separate business fields and make use of the knowledge to analyze complex business problems of the general manager.

2. Chandler noted that although he did not read Penrose's (1959) work until after he had completed his own work, the two works were in support of each other. Especially relevant were Penrose's (1959) Chapter 5 "Inherited Resources and the Directions of Expansion" and Chapter 7 "The Economics of Diversification" (1962: 453).

\section{References}

Alchian, A. A., \& Demsetz, H. 1972. Production, information costs and economic organization. American Economic Review, 62: 777-795.

Almeida, P. 1996. Knowledge sourcing by foreign multinationals: Patent citation analysis in the U.S. semiconductor industry. Strategic Management Journal, 17: 155-165.

Amit, R., \& Schoemaker, P. J. H. 1993. Strategic assets and organizational rent. Strategic Management Journal, 14: $33-46$.

Andrews, K. 1971. The concepts of corporate strategy. Homewood, IL: Dow Jones-Irwin.

Ansoff, H. I. 1965. Corporate strategy. New York: McGraw Hill.

Bain, J. S. 1956. Barriers to new competition. Cambridge: Harvard University Press.

Bain, J. S. 1968. Industrial organization (2nd ed.). New York: Wiley.

Barnard, C. I. 1938. The functions of the executive. Cambridge, MA: Harvard University Press.

Barnett, W. P. \& Burgelman, R. A. 1996. Evolutionary perspectives on strategy. Strategic Management Journal, 17 (Special Issue): 5-19.

Barnett, W. P., Greve, H. R., \& Park, D. Y. 1994. An evolutionary model of organizational performance. Strategic Management Journal, 15 (Speical Issue): 11-28.

Barney, J. B. 1986a. Types of competition and the theory of strategy: Toward an integrative framework. Academy of Management Review, 11: 791-800.

Barney, J. B. 1986b. Organizational culture: Can it be a source of sustained competitive advantage? Academy of Management Review, 11: 656-665.

Barney, J. B. 1991 Firm resources and sustained competitive advantage. Journal of Management, 17: 99-120.

Barney, J. B., \& Hoskisson, R. E. 1990. Strategic groups, untested assertions and research proposals. Managerial and Decision Economics, 11: 187-198.

Barr, P. S., Stimpert, J. L., \& Huff, A. S. 1992. Cognitive change, strategic action and organizational renewal. Strategic Management Journal, 13 (Special Issue): 15-36.

Baum, J. A. C., \& Korn, H. J. 1996. Competitive dynamics of interfirm rivalry. Academy of Management Journal, 39: 255-191.

Baysinger, B., \& Hoskisson, R. E. 1989. Diversification strategy and R\&D intensity in multiproduct firms. Academy of Management Journal, 32: 310-332.

Baysinger, B., Kosnik, R. D., \& Turk, T. A. 1991. Effects of board and ownership structure on corporate R\&D strategy. Academy of Management Journal, 34: 205-214.

Bernheim, D., \& Whinston, M. D. 1990. Multimarket contact and collusive behavior. Rand Journal of Economics, 21: 1-26.

Bethel, J. E., \& Liebeskind, J. 1993. The effects of ownership structure on corporate restructuring. Strategic management Journal, 14 (Special Issue): 15-31.

Berle, A. A., \& Means, G. C. 1932. The modern corporation and private property. New York: MacMillan.

Bettis, R. A., \& Hitt, M. A. 1995. The new competitive landscape. Strategic Management Journal, 16 (Special Issue): 7-19.

Biggadike, R. 1981. The contributions of marketing to strategic management. Academy of Management Review, 6: 621-632.

Black, J. A., \& Boal, K. B. 1994. Strategic resources: Traits, configurations and paths to sustainable competitive advantage. Strategic Management Journal, 15 (Special Issue): 131-148.

Blodgett, L. L. 1992. Factors in the instability of international joint ventures: An event history analysis. Strategic Management Journal, 13: 475-481.

Boeker, W., Goodstein, J., Stephan, J., \& Murmann, J. P. 1997. Competition in a multi-market environment: The case of market exit. Organization Science, 8: 126-142.

Boyacigiller, N. A., \& Adler, N. J. 1991. The parochial dinosaur: Organizational science in a global context. Academy of Management of Review, 16: 262-290. 
Brander, J. A., \& Eaton, J. 1984. Product line rivalry. American Economic Review, 74: 323-334.

Brown, S. L., \& Eisenhardt, K. M. 1995. Product development: Past research, present findings, and further directions. Academy of Management Review, 20: 343-378.

Buckley, P. J., \& Casson, M. C. 1981. The future of multinational enterprise. London: MacMillan.

Bulow, J. I., Geanakoplos, J. D., \& Klemperer, P. D. 1985. Multimarket oligopoly: Strategic substitutes and complements. Journal of Political Economy, 93: 488-511.

Camerer, C. F., \& Weigelt, K. 1988. Experimental tests of a sequential equilibrium reputation model. Econometrica, 56: 1-36.

Cannella, A. A., \& Hambrick, D. C. 1993. Effects of executive departures on the performance of acquired firms. Strategic Management Journal, 14 (Special Issue): 137-152.

Caves, R. E., \& Porter, M. E. 1977. From entry barriers to mobility barriers: Conjectural decisions and contrived deterrence to new competition. Quarterly Journal of Economics, 91: 241-261.

Chandler, A. D. 1962. Strategy and structure. Cambridge, MA: MIT Press.

Chatterjee, S., \& Wernerfelt, B. 1991. The link between resources and type of diversification: Theory and evidence. Strategic Management Journal, 12: 33-48.

Chen, M.-J. 1996. Competitor analysis and interfirm rivalry: Toward a theoretical integration. Academy of Management Review, 21: 100-134.

Chen, M.-J., \& MacMillan, I. C. 1992. Nonresponse and delayed response to competitive moves: The roles of competitor dependence and action irreversibility. Academy of Management Journal, 35: 539-570.

Chen, M.-J., \& Miller, D. 1994. Competitive attack, retaliation and performance: An expectancy-valence framework. Strategic Management Journal, 15: 85-102.

Child, J. 1972. Organization structure, environment, and performance: The role of strategic choice. Sociology, 6: 1-22.

Coase, R. H. 1937. The nature of the firm. Economica, 4: 386-406.

Cohen, W. M., \& Levinthal, D. A. 1990. Absorptive capacity: A new perspective on learning an innovation. Administrative Science Quarterly, 35: 128-152.

Collis, D. J. 1991. A resource-based analysis of global competition: The case of the bearings industry. Strategic Management Journal, 12 (Special Issue): 49-68.

Conner, K. 1991. An historical comparison of resource-based logic and five schools of thought within industrial organization economics: Do we have a new theory of the firm here? Journal of Management, 17: 121-154.

Conner, K. R., \& Prahalad, C. K. 1996. A resource-based theory of the firm: Knowledge versus opportunism. Organization Science, 7 (5): 477-501.

Cool, K., \& Schendel, D. E. 1987. Strategic group formation and performance: The case of the U.S. pharmaceutical industry, 1963-1982. Management Science, 33: 1102-1124.

Cyert, R. M., \& March, J. G. 1963. A behavioral theory of the firm. Englewood Cliffs, NJ: Prentice-Hall.

Dacin, M. T., Hitt, M. A., \& Levitas, E. 1997. Selecting partners for successful international alliances: Examination of U.S. and Korea firms. Journal of World Business, 32: 3-16.

D’Aveni, R. 1994. Hypercompetition. New York: Free Press.

Davis, J. H., Schoorman, F. D., \& Donaldson, L. 1997. Toward a stewardship theory of management. Academy of Management Review, 22 (1): 20-47.

Dean, T. J., Brown, R. L., \& Bamford, C. E. 1998. Differences in large and small firm responses to environmental context: Strategic implications from a comparative analysis of business formations. Strategic Management Journal, 19 (8): 709-728.

Dess, G. G., Gupta, A., Hennart, J. F., \& Hill, C. W. L. 1995. Conducting and integrating strategy research at the international, corporate, and business levels: Issues and directions. Journal of Management, 21 (3): 357-393.

Dess, G. G., Ireland, R. D., \& Hitt, M. A. 1990. Industry effects and strategic management research. Journal of Management, 16: 7-27.

Donaldson, L. 1990. The ethereal hand: Organizational economics and management theory. Academy of Management Review, 15: 369-401.

Dierickx, I., \& Cool, K. 1989. Asset stock accumulation and sustainability of competitive advantage. Management Science, 35: 1504-1511.

Doz, Y. L. 1996. The evolution of cooperation in strategic alliances: Initial conditions or learning processes? Strategic Management Journal, 17 (Special issue): 55-84.

Dubin, R. 1969. Theory building. New York: Free Press.

Dyer, J. H. 1996. Specialized supplier networks as a source of competitive advantage: Evidence from the auto industry. Strategic Management Journal, 17: 271-291.

Dyer, J. H. 1997. Effective interfirm collaboration: How firms minimize transaction costs and maximize transaction value. Strategic Management Journal, 18: 535-556. 
Edwards, C. D. 1955. Conglomerate bigness as a source of power. In Business concentration and price policy: 331-352. A conference of the University-national Bureau Committee for Economic research. Princeton, NJ: Princeton University Press.

Eisenhardt, K. M. 1989a. Agency theory: An assessment and review. Academy of Management Review, 14: $57-74$.

Eisenhardt, K. M. 1989b. Making fast strategic decisions in high-velocity environments. Academy of Management Journal, 39: 543-576.

Fama, E. F. 1980. Agency problems and the theory of the firm. Journal of Political Economy, 88: 288-307.

Fama, E. F., \& Jensen, M. C. 1983. Separation of ownership and control. Journal of Law and Economics, 26: 301-325.

Farjoun, M. 1994. Beyond industry boundaries: Human expertise, diversification and resource-related industry groups. Organization Science, 5: 185-199.

Fayol, H. 1949. General and Industrial management. New York: Pitman.

Fiegenbaum, A., \& Thomas, H. 1995. Strategic groups as referential groups: Theory, modeling and empirical examination of industry and competitive strategy. Strategic Management Journal, 16: 461-476.

Finkelstein, S., \& Hambrick, D. C. 1990. Top management tenure and organizational outcomes: The moderating role of managerial discretion. Administrative Science Quarterly, 35: 84-503.

Finkelstein, S., \& Hambrick, D. 1996. Strategic leadership. St. Paul: West Educational Publishing.

Fiol, C. M. 1991. Management culture as a competitive resource: An identity-based view of sustained competitive advantage. Journal of Management, 17: 191-211.

Foss, N. J. 1996. More critical comments on knowledge-based theories of the firm. Organization Science, 7 (5): 51-523.

Friedman, M. 1953. Essays in positive economics. Chicago: University of Chicago Press.

Ghoshal, S., \& Moran, P. 1996. Bad for practice: A critique of the transaction cost theory. Academy of Management Review, 21: 13-47.

Gimeno, J. 1994. Multipoint competition, market rivalry and firm performance: A test of the mutual forbearance hypothesis in the United States airline industry, 1984-1988. Unpublished dissertation, Purdue University.

Gimeno, J., \& Woo, C. Y. 1996. Hypercompetition in a multi-market environment: The role of strategic similarity and multi-market contact in competitive de-escalation. Organization Science, 7: 322-341.

Ginsberg, A. 1988. Measuring and modeling changes in strategy: Theoretical foundations and empirical directions. Strategic Management Journal, 9: 559-575.

Ginsberg, A. 1989. Construing the business portfolio: A cognitive model of diversification. Journal of Management Studies, 26: 417-438.

Godfrey, P. C., \& Hill, C. W. L. 1995. The problem of unobservables in strategic management research. Strategic Management Journal, 16: 519-533.

Gomes-Casseres, B. 1996. The alliance revolution: The new shape of business rivalry. Cambridge, MA: Harvard University Press.

Gomez-Mejia, L. R. 1994. Executive compensation: A reassessment and a future research agenda. Research in personnel and human resources management, 12: 161-222.

Gordon, R. A., \& Howell, J. E. 1959. Higher education for business. New York: Columbia University Press.

Grant, R. M. 1991. The resource-based theory of competitive advantage. California Management Review, 33 (3): $114-135$.

Greening, T. 1979. Diversification, strategic groups and the structure-conduct-performance relationship: A synthesis. Review of Economics and Statistics, 62: 475-477.

Greve, H. R. 1996. Patterns of competition: the diffusion of a market position in radio broadcasting. Administrative Science Quarterly, 41: 29-60.

Grimm, C. M., \& Smith, K. G. 1997. Strategy as action: Industry rivalry and coordination. Cincinnati: South-Western College Publishing.

Gulati, R. 1995. Social structure and alliance formation patterns: A longitudinal analysis. Administrative Science Quarterly, 40: 619-652.

Haleblian, J., \& Finkelstein, S. 1993. Top management team size, CEO dominance, and firm performance: The moderating roles of environmental turbulence and discretion. Academy of Management Journal, 36: $844-863$.

Hambrick, D. C., \& Abrahamson, E. 1995. Assessing the amount of managerial discretion in different industries: A multimethod approach. Academy of Management Journal, 38: 1427-1441.

Hambrick, D. C., \& Finkelstein, S. 1987. Managerial discretion: A bridge between polar views of organizations. In L. L. Cummings \& B. M. Staw (Eds.), Research in organizational behavior, vol. 9: 369-406. Greenwich, CT: JAI Press.

Hambrick, D. C., \& Mason, P. A. 1984. Upper echelons: The organization as a reflection of its to managers. Academy of Management Review, 9: 193-206.

Hatten, K. J. 1974. Strategic models in the brewing industry. Unpublished Ph.D. dissertation, Purdue University. 
Hatten, K. J., \& Hatten, M. L. 1987. Strategic groups, asymmetrical mobility barriers and contestability. Strategic Management Journal, 8: 329-342.

Hatten, K. J., \& Schendel, D. E. 1977. Heterogeneity within an industry. Journal of Industrial Economics, 10: $399-411$.

Hatten, K. J., Schendel, D. E., \& Cooper, A. C. 1978. A strategic model of the U.S. brewing industry: 1925-1971. Academy of Management Journal, 21: 592-619.

Helmich, D. L., \& Brown, W. B. 1972. Successor type and organizational change in the corporate enterprise. Administrative Science Quarterly, 17: 371-378.

Henderson, R., \& Cockburn, I. 1994. Measuring competence? Exploiting firm effects in pharmaceutical research. Strategic Management Journal, 15 (Special Issue): 63-84.

Hennart, J. F. 1988. A transactions costs theory of equity joint ventures. Strategic Management Journal, 9: $361-374$.

Hennart, J. F., \& Park, Y. R. 1993. Greenfield vs. acquisition: The strategy of Japanese investors in the United States. Management Science, 39: 1054-1070.

Hennart, J. F., \& Park, Y. R. 1994. Location, governance, and strategic determinants of Japanese manufacturing investment in the United States. Strategic Management Journal, 15: 419-436.

Hill, C. W. L. 1985. Oliver Williamson and the M-form: A critical review. Journal of Economic Issues, 19: 731-751.

Hill, C. W. L. 1990. Cooperation, opportunism, and the invisible hand: Implications for transaction cost theory. Academy of Management Review, 15: 500-513.

Hill, C. W. L., \& Hoskisson, R. E. 1987. Strategy and structure in the multiproduct firm. Academy of Management Review, 12: 331-341.

Hill, C. W. L., Hitt, M. A., \& Hoskisson, R. E. 1992. Cooperative versus competitive structures in related and unrelated diversified firms. Organization Science, 3: 501-521.

Hill, C. W. L., \& Kim, W. C. 1988. Searching for a dynamic theory of the multinational enterprise: A transaction cost model. Strategic Management Journal, 9 (Special Issue): 93-104.

Hill, C. W. L., \& Snell, S. A. 1988. External control, corporate strategy, and firm performance in researchintensive industries. Strategic Management Journal, 9: 577-590.

Hitt, M. A. 1998. Twenty-first century organizations: Business firms, business schools, and the Academy. Academy of Management Review, 23: 218-224.

Hitt, M. A., Dacin, M. T., Tyler, B. B., \& Park, D. 1997. Understanding the differences in Korean and U.S. executives' strategic orientations. Strategic Management Journal, 18: 159-167.

Hitt, M. A., Gimeno, J., \& Hoskisson, R. E. 1998. Current and future research methods in strategic management. Organizational Research Methods, 1: 6-44.

Hitt, M. A., Harrison, J. S., Ireland, R. D., \& Best, A. 1998. Attributes of successful and unsuccessful acquisitions of U.S. firms. British Journal of Management, 9: 91-114.

Hitt, M. A., \& Hoskisson, R. E., \& Ireland, R. D. 1990. Mergers and acquisitions and managerial commitment to innovation in M-form firms. Strategic Management Journal, 11 (Special Issue): 29-47.

Hitt, M. A., Hoskisson, R. E., Johnson, R. A., \& Moesel, D. D. 1996. The market for corporate control and firm innovation. Academy of Management Journal, 39: 1084-1119.

Hitt, M. A., Hoskisson, R. E., \& Kim, H. 1997. International diversifications: Effects on innovation and firm performance in product-diversified firms. Academy of Management Journal, 40: 767-798.

Hitt, M. A., \& Ireland, R. D. 1985. Corporate distinctive competence, strategy, industry and performance. Strategic Management Journal, 6: 273-293.

Hitt, M. A., \& Ireland, R. D. 1986. Relationships among corporate-level distinctive competencies, diversification strategy, corporate structure and performance. Journal of Management Studies, 23: 401-416.

Hitt, M. A., \& Ireland, R. D., \& Hoskisson, R. E. 1997. Strategic management: Competitiveness and globalization. St. Paul: West Educational Publishing.

Hitt, M. A., Ireland, R. D., \& Palia, K. A. 1982. Industrial firms' grand strategy and functional importance: Moderating effects of technology and uncertainty. Academy of Management Journal, 25: 265-298.

Hitt, M. A., Ireland, R. D., \& Stadter, G. 1982. Functional importance and company performance: Moderating effects of grand strategy and industry type. Strategic Management Journal, 3: 315-330.

Hitt, M. A., Keats, B. W., \& DeMarie, S. M. 1998. Navigating in the new competitive landscape: Building strategic flexibility and competitive advantage in the twenty-first century. Academic of Management Executive, 12 (4): 22-42.

Hitt, M. A., Nixon, R. D., Hoskisson, R. E., \& Kochhar, R. in press. Corporate entrepreneurship and cross-functional fertilization: Activation, process and disintegration of a new product design team. Entrepreneurship Theory and Practice.

Hitt, M. A, \& Tyler, B. B. 1991. Strategic decision models: integrating different perspectives. Strategic Management Journal, 12: 327-351.

Hofer, C. W., \& Schendel, D. 1978. Strategy formulation: Analytical concepts. St. Paul, MN: West Publishing. 
Hoskisson, R. E. 1987. Multidivisional structure and performance: the contingency of diversification strategy. Academy of Management Journal, 30: 625-644.

Hoskisson, R. E., Eden, L., Lau, C. M., \& Wright, M. in press. Enterprise strategies in transitional and emerging economies. Academy of Management Journal.

Hoskisson, R. E., \& Galbraith, C. S. 1985. The effect of quantum versus incremental M-form reorganization on performance: A time-series exploration of intervention dynamics. Journal of Management, 11: 55-70.

Hoskisson, R. E., Harrison, J. S., \& Dubofsky, D. A. 1991. Capital market evaluation of M-form implementation and diversification strategy. Strategic Management Journal, 12: 271-279.

Hoskisson, R. E., Hill, C. W. L., \& Kim, H. 1993. The multidivisional structure: Organizational fossil or source of value? Journal of Management, 19: 269-298.

Hoskisson, R. E., \& Hitt, M. A. 1990. Antecedents and performance outcomes of diversification: A review and critique of theoretical perspectives. Journal of Management, 16: 461-509.

Hoskisson, R. E., \& Hitt, M. A. 1994. Downscoping: How to tame the diversified firm. New York: Oxford University Press.

Hoskisson, R. E., \& Hitt, M. A., \& Hill, C. W. L. 1993. Managerial incentives and investment in R\&D in large multiproduct firms. Organization Science, 4: 325-341.

Hoskisson, R. E., Hitt, M. A., Turk, T. A., \& Tyler, B. B. 1989. Balancing corporate strategy and executive compensation: Agency theory and corporate governance. In G. R. Ferris \& K. M. Rowland (eds.), Research in personnel and human resources management, 7: 25-57. Greenwich, CT: JAI Press.

Hoskisson, R. E., \& Johnson, R. A. 1992. Corporate restructuring and strategic change: The effect on diversification strategy and R\&D intensity. Academy of Management Journal, 13: 625-634.

Hoskisson, R. E., Johnson, R. A., \& Moesel, D. D. 1994. Corporate divestiture intensity in restructuring firms: Effects of governance, strategy, and performance. Academy of Management Journal, 37: 1207-1251.

Hoskisson, R. E., \& Turk, T. A. 1990. Corporate restructuring: Governance and control limits of the internal capital market. Academy of Management Review, 15: 459-477.

Hrebiniak, L. G., \& Joyce, W. F. 1985. Organizational adaptation: Strategic choice and environmental determinism. Administrative Science Quarterly, 30: 336-349.

Huff, A. S. 1982. Industry influence on strategy reformulation. Strategic Management Journal, 3: 119-131.

Huff, A. S. 1990. Mapping strategic thought. In A. S. Huff (Ed.), Mapping strategic thought: 11-49. Chichester, UK: John Wiley \& Sons.

Hunt, M. S. 1972. Competition in the major home appliance industry, 1960-1970. Unpublished Ph.D. dissertation, Harvard University.

Itami, H. 1987. Mobilizing invisible assets. Cambridge, MA: Harvard University Press.

Jemison, D. B. 1981a. The contributions of administrative behavior to strategic management. Academy of Management Review, 6: 633-642.

Jemison, D. B. 1981b. The importance of an integrative approach to strategic management research. Academy of Management Review, 6: 601-608.

Jensen, M. C., \& Meckling, W. 1976. Theory of the firm: Managerial behavior, agency costs and ownership structure. Journal of Financial Economics, 3: 305-360.

Johnson, R. A., Hoskisson, R. E., \& Hitt, M. A. 1993. Board of director involvement in restructuring: The effects of board versus managerial controls and characteristics. Strategic Management Journal, 14 (Special Issue): 33-50.

Judge, W. Q. Jr., \& Zeithaml, C. P. 1992. Institutional and strategic choice perspectives on board involvement in the strategic decision process. Academy of Management Journal, 35: 766-794.

Karnani, A., \& Wernerfelt, B. 1985. Multiple point competition. Strategic Management Journal, 6: 87-96.

Keats, B. W., \& Hitt, M. A. 1988. A causal model of linkages among environmental dimensions, macro organizational characteristics, and performance. Academy of Management Journal, 31: 570-598.

Kesner, I. F., \& Sebora, T. C. 1994. Executive succession: Past, present, \& future. Journal of Management, 20 : 327-372.

Kochhar, R., \& David, P. 1996. Institutional investors and firm innovation: A test of competing hypotheses. Strategic Management Journal, 17: 73-84.

Kochhar, R., Hitt, M. A., \& Bierman, L. 1996. Effects of human capital and reputation on the diversificationperformance relationship in law firms: A test of the resource-based view. Paper presented at the Strategic Management Society meetings, Phoenix.

Kogut, B. 1988. Joint ventures: Theoretical and empirical perspectives. Strategic management Journal, 9: $319-332$.

Kogut, B., \& Zander, U. 1992. Knowledge of the firm, combinative capabilities, and the replication of technology. Organization Science, 3: 383-397.

Kogut, B., \& Zander, U. 1996. What firms do? Coordination, identity, and learning. Organization Science, 7 (5): $502-518$.

JOURNAL OF MANAGEMENT, VOL. 25, NO. 3, 1999 
Kosnik, R. D. 1990. Effects of board demography and directors' incentives on corporate greenmail decisions. Academy of Management Journal, 33: 129-150.

Kotha, S. 1995. Mass customization: Implementing the emerging paradigm for competitive advantage. Strategic Management Journal, 16 (Special issue): 21-42.

Kotter, J. P. 1982. The general managers. New York: Free Press.

Larsson, R. 1993. Case survey methodology: Quantitative analysis of patterns across case studies. Academy of Management Journal, 36: 1515-1546.

Learned, E. P., Christensen, C. R., Andrews, K. R., \& Guth, W. D. 1965/1969. Business Policy: Text and Case (rev. ed.). Homewood, IL: Richard D. Irwin.

Lei, D., Hitt, M. A., \& Bettis, R. A. 1996. Dynamic core competences through meta-learning and strategic context. Journal of Management, 22: 549-569.

Leonard-Barton, D. 1992. Core capabilities and core rigidities: A paradox in managing new product development. Strategic Management Journal, 13 (Special Issue): 111-125.

Lippman, S., \& Rumelt, R. P. 1982. Uncertainty imitability: An analysis of interfirm differences in efficiency under competition. Bell Journal of Economics, 13: 418-453.

Mahoney, J. T., \& Pandian, J. R. 1992. The resource-based view within the conversation of strategic management. Strategic Management Journal, 13: 363-380.

Mallette, P., \& Fowler, K. L. 1992. Effects of board composition and stock ownership on the adoption of poison pills. Academy of Management Journal, 35: 1010-1035.

March, J. C., \& Simon, H. A. 1958. Organizations. New York: Wiley.

Markides, C. C., \& Williamson, P. J. 1994. Related diversification, core competencies and corporate performance. Strategic Management Journal, 15 (Special Issue): 149-166.

Markoczy, L., \& Goldberg, J. 1995. A method for eliciting and comparing causal maps. Journal of Management, 21: 305-333.

Mascarenhas, B. 1989. Strategic group dynamics. Strategic Management Journal, 32: 333-352.

Mason, E. S. 1939. Price and production policies of large scale enterprises. American Economic Review, 29 : 61-74.

McGahan, A. M., \& Porter, M. E. 1997. How much does industry matter, really? Strategic Management Journal, 18: $15-30$.

McWilliams, A., \& Siegel, D. 1997. Event studies in management research: Theoretical and empirical issues. Academy of Management Journal, 40: 626-657.

Miller, D., \& Droge, C. 1986. Psychological and traditional determinants of structure. Administrative Science Quarterly, 31: 539-560.

Miller, D., \& Friesen, P. H. 1984. Organizations: A quantum view. Englewood Cliffs, NJ: Prentice-Hall.

Miller, D., \& Shamsie, J. 1996. The resource-based view of the firm in two environments: The Hollywood film studios from 1936-1965. Academy of Management Journal, 39: 519-543.

Mintzberg, H. 1973. The nature of managerial work. New York: Harper and Row.

Montgomery, C. A. 1995. Of diamonds and rust: A new look at resources. In C. A. Montgomery (Ed.), Resources in an evolutionary perspective: A synthesis of evolutionary and resource-based approaches to strategy. Norwell, MA and Dordrecht: Kluwer Academic.

Moran, P., \& Ghoshal, S. 1996. Theories and economic organization: The case for realism and balance. Academy of Management Review, 21: 58-72.

Murray, A. I. 1989. Top management group heterogeneity and firm performance. Strategic Management Journal, 10: 125-141.

Nelson, R. R. 1991 Why do firms differ and how does it matter? Strategic Management Journal, 12 (Special Issue): $61-74$

Nelson, R. R., \& Winter, S. G. 1982. An evolutionary theory of economic change. Cambridge, MA: Harvard University Press.

Noda, T., \& Bower, J. L. 1996. Strategy making as interrated processes of resource allocation. Strategic Management Journal, 17 (Special Issue): 159-192.

Nonaka, I. 1991. The knowledge-creating company. Harvard Business Review, 69 (6): 96-104.

Nonaka, I. 1994. A dynamic theory of organizational knowledge creation. Organization Science, 5: 14-37.

Nonaka, I., \& Takeuchi, H. 1995. The knowledge creating company. New York: Oxford University Press.

Newman, H. 1973. Strategic groups and the structure-performance relationships: A study with respect to the chemical process industries. Unpublished Ph.D. dissertation, Harvard University.

Newman, H. 1978. Strategic groups and the structure-performance relationship. Review of Economics and Statistics, 60: 417-427.

Oliver, C. 1997. Sustainable competitive advantage: Combining institutional and resource-based views. Strategic Management Journal, 18: 697-713.

Osborn, R. N., \& Hagedoorn, J. 1997. The institutionalization and evolutionary dynamics of interorganizational alliances and networks. Academic of Management Journal, 40: 261-278. 
Oster, S. 1982. Intraindustry structure and the ease of strategic change. Review of Economics and Statistics: 376-384.

Patton, G. R. 1976. A simulation equation model of corporate strategy: The case of the U.S. brewing industry. Unpublished Ph.D. dissertation, Purdue University.

Penrose, E. T. 1959. The theory of the growth of the firm. New York: Wiley.

Peteraf, M. A. 1993. The cornerstones of competitive advantage: A resource-based view. Strategic Management Journal, 14: 179-191.

Peteraf, M., \& Shanley, M. 1997. Getting to know you: A theory of strategic group identity. Strategic Management Journal, 18: 165-186.

Pfeffer, J., \& Davis-Blake, A. 1986. Administrative succession and organizational performance: How administrator experience mediates the succession effect. Academy of Management Journal, 26: 72-83.

Pisano, G. P. 1994. Knowledge, integration, and the locus of learning: An empirical analysis of process development. Strategic Management Journal, 15 (Special Issue): 85-100.

Polanyi, M. 1966. The tacit dimension. New York: Anchor Day.

Porac, J. F., Thomas, H., Wilson, F., Paton, D., \& Kanfer, A. 1995. Rivalry and the industry model of Scottish knitwear producers. Administrative Science Quarterly, 40: 203-227.

Porter, M. E. 1973. Retailer power, manufacturer strategy, and performance in consumer goods industry. Unpublished Ph.D. dissertation, Harvard University.

Porter, M. E. 1979. The structure within industries and companies' performance. Review of Economics and Statistics, 61: 214-228.

Porter, M. E. 1980. Competitive strategy. New York: Free Press.

Porter, M. E. 1981. The contribution of industrial organization to strategic management. Academy of Management Review, 6: 609-620.

Porter, M. E. 1985. Competitive advantage. New York: Free Press.

Porter, M. E. 1991. Towards a dynamic theory of strategy. Strategic Management Journal, 12 (Special Issue): 95-117.

Porter, M. E. 1996. What is strategy? Harvard Business Review, 74 (6): 61-78.

Porter, M. E. 1998a. On competition. Boston: Harvard Business School Publishing.

Porter, M. E. 1998b. Clusters and the new economics of competition. Harvard Business Review, 76 (6): 77-90.

Porter, L. W., \& McKibbin, L. E. 1988. Management education and development: Drift of thrust into the $21^{\text {st }}$ century. New York: McGraw-Hill.

Pouder, R., \& St. John, C. 1996. Hot spots and blind spots: Geographical clusters of firms and innovation. Academy of Management Review, 21: 1192-1225.

Prahalad, C. K., \& Bettis, R. 1986. The dominant logic: A new linkage between diversity and performance. Strategic Management Journal, 7: 485-501.

Prahalad, C. K., \& Hamel, G. 1990. The core competence of the corporation. Harvard Business Review, 68 (3): 79-91.

Reger, R. K., \& Huff, A. S. 1993. Strategic groups: A cognitive perspective. Strategic Management Journal, 14: $103-124$.

Robins, J. A. 1992. Organizational considerations in the evaluation of capital assets: Toward a resource-based view of strategic investment by firms. Organization Science, 3: 522-536.

Robins, J., \& Wiersema, M. F. 1995. A resource-based approach to the multibusiness firm: Empirical analysis of portfolio interrelationships and corporate financial performance. Strategic Management Journal, 16: 277-299.

Roquebert, J. A., Phillips, R. P., \& Westfall, P. A. 1996. Markets vs. management: What 'drives' profitability. Strategic Management Journal, 17: 653-664.

Rugman, A. M. 1981. Inside the multinationals: The economics of internal markets. New York: Columbia University Press.

Rumelt, R. P. 1974. Strategy, structure, and economic performance. Boston, MA: Harvard Business School Press.

Rumelt, R. P. 1984. Toward a strategic theory of the firm. In R. Lamb (Ed.), Competitive strategic management: 556-570. Englewood Cliffs: NJ: Prentice-Hall.

Rumelt, R. P. 1987. Theory, strategy, and entrepreneurship. In D. J. Teece (Ed.), The competitive challenge: 137-158. Cambridge, MA: Ballinger Publishing.

Rumelt, R. P. 1991. How much does industry matter? Strategic Management Journal, 12: 167-185.

Rumelt, R. P., Schendel, D., Teece, D. J. 1991. Strategic management and economics. Strategic Management Journal, 12 (Special Issue): 5-29.

Rumelt, R. P., Schendel, D. E., \& Teece, D. J. 1994. Fundamental issues in strategy: A research agenda. Boston, MA: Harvard Press School Press.

Sanchez, R. 1995. Strategic flexibility and product competition. Strategic Management Journal, 16 (Speical Issue): $135-159$.

JOURNAL OF MANAGEMENT, VOL. 25, NO. 3, 1999 
Schendel, D. 1996. Evolutionary perspectives on strategy. Strategic Management Journal, 17, Summer (Special Issue): $1-4$.

Schendel, D., \& Hatten, K. J. 1972. Business policy or strategic management: A broader view for an emerging discipline. Academy of Management Proceedings, 99-102.

Schendel, D. E., \& Hofer, C. W. 1979. Strategic management: A new view of business policy and planning. Boston: Little, Brown \& Co.

Selznick, P. 1957. Leadership in administration: A sociological interpretation. New York: Harper \& Row.

Simon, H. A. 1945. Administrative behavior. New York: Macmillan.

Singh, K. 1995. The impact of technological complexity and interfirm cooperation on business survival. Academy of Management Best papers Proceedings: 67-72.

Smith, J. E., Carson, K. P., \& Alexander, R. A. 1984. Leadership: It can make a difference. Academy of Management Journal, 27: 765-776.

Smith, K. G., Grimm, C. M., Chen, M. J., \& Gannon, M. J. 1989. Predictors of competitive strategic actions: Theory and preliminary evidence. Journal of Business Research, 18: 245-258.

Smith, K. G., \& Grimm, C. M., \& Gannon, M. J. 1992. Dynamics of competitive strategy. Newsbury Park: CA: Sage Publications.

Smith, K. G., Grimm, C. M., Gannon, M. J., \& Chen, M.-J. 1991. Organizational information processing, competitive responses and performance in the U.S. domestic airline industry. Academy of Management Journal, 34: 60-85.

Smith, K. G., Smith, K. A., Olian, J. D., Sims, Jr., H. P., O’Bannon, D. P., \& Scully, J. A. 1994. Top management demography and process: The role of social integration and communication. Administrative Science Quarterly, 39: 412-438.

Snow, C. C., \& Hrebiniak, L. G. 1980. Strategy, distinctive competence, and organizational performance. Administrative Science Quarterly, 25: 317-336.

Spender, J. C. 1989. Industry recipes: An enquiry into the nature and sources of managerial judgement. Oxford, Blackwell.

Spender, J. C., \& Grant, R. M. 1996. Knowledge and the firm: Overview. Strategic Management Journal, 17 (Special Issue): 5-9.

Stimpert, J. L., \& Duhaime, I. M. 1997. Seeing the big picture: The influence of industry, diversification, and business strategy on performance. Academy of Management Journal: 40: 560-583.

Stuart, T. E., \& Podolny, J. M. 1996. Local search and the evolution of technological capabilities. Strategic Management Journal, 17 (Special Issue): 21: 38.

Sundaramurthy, C. 1996. Corporate governance within the context of antitakeover provisions. Strategic Management Journal, 17: 377-394.

Teece, D. J., Pisano, G., \& Shuen, A. 1997. Dynamic capabilities and strategic management. Strategic Management Journal, 18: 509-533.

Thompson, J. D. 1967. Organizations in action: Social science bases of administrative theory. New York: McGraw-Hill.

Tosi, H. L., \& Gomez-Mejia, L. R. 1989. The decoupling of CEO pay and performance: An agency theory perspective. Administrative Science Quarterly, 34: 169-189.

Tsui, A. S. 1984. A role set analysis of managerial reputation. Organizational Behavior and Human Performance, 34: 64-96.

Tushman, M. L., \& Andersen, P. 1986. Technological discontinuities and organizational environments. Administrative Science Quarterly, 31: 439-465.

Walsh, J. P., \& Kosnik, R. D. 1993. Corporate raiders and their disciplinary rile in the market for corporate control. Academy of Management Journal, 36: 671-700.

Walsh, G. F., \& Seward, J. K. 1990. On the efficiency of internal and external corporate control mechanisms. Academy of Management Review, 15: 421-458.

Wernerfelt, B. 1984. A resource-based view of the firm. Strategic Management Journal, 5: 171-180.

Wernerfelt, B. 1995. The resource-based view of the firm: Ten years after. Strategic Management Journal, 16 : $171-174$.

Wiggins, R., \& Ruefli, T. 1995. Necessary conditions for the predictive validity of strategic groups: Analysis without reliance on clustering techniques. Academy of Management Journal, 38: 1635-1656.

Wiersema, M. F., \& Liebeskind, J. P. 1995. The effects of leveraged buyouts on corporate growth and diversification in large firms. Strategic Management Journal, 16: 447-460.

Williamson, O. E. 1975. Markets and hierarchies. New York: Free Press.

Williamson, O. E. 1985. The economic institutions of capitalism. New York: Free Press.

Williamson, O. E. 1991. Comparative economic organization: The analysis of discrete structural alternatives. Administrative Science Quarterly, 36: 269-296.

Williamson, O. E. 1996. Economic organization: The case for candor. Academy of Management Review, 21: $48-57$. 
Wright, P., \& Ferris, S. P. 1997. Agency conflict and corporate strategy: The effect of divestment on corporate value. Strategic Management Journal, 18: 77-83.

Zahra, S., \& Pearce, J. A. 1989. Boards of directors and corporate financial performance: A review and integrative model. Journal of management, 15: 291-334.

Zajac, E. 1995. SMJ 1994 best paper prize to Birger Wernerfelt. Strategic Management Journal, 16: 169-170.

Zajac, E., \& Westphal, J. D. 1996. Who shall succeed? How CEO/board preferences and power affect the choice of new CEOs. Academy of Management Journal, 39: 64-90.

Zander, U., \& Kogut, B. 1995. Knowledge and the speed of the transfer and imitation of organizational capabilities: An empirical test. Organizational Science, 6: 76-92. 